\title{
Effect of Salinity Intrusion on Food Crops, Livestock, and Fish Species at Kalapara Coastal Belt in Bangladesh
}

\author{
Mohammad Zahangeer Alam, ${ }^{1}$ Lynne Carpenter-Boggs, ${ }^{2}$ \\ Shishir Mitra, ${ }^{1}$ Md. Manjurul Haque, ${ }^{1}$ Joan Halsey, ${ }^{3}$ M. Rokonuzzaman, ${ }^{4}$ \\ Badhan Saha, ${ }^{5}$ and M. Moniruzzaman ${ }^{5}$ \\ ${ }^{1}$ Department of Environmental Science, Bangabandhu Sheikh Mujibur Rahman Agricultural University (BSMRAU), \\ Gazipur 1706, Bangladesh \\ ${ }^{2}$ Department of Crop and Soil Sciences, Washington State University, Pullman, WA 99164-6420, USA \\ ${ }^{3}$ Washington State University, Pullman, WA 99164-3615, USA \\ ${ }^{4}$ Department of Agricultural Extension and Rural Development, BSMRAU, Gazipur 1706, Bangladesh \\ ${ }^{5}$ Soil and Environment Section, Biological Research Division, Bangladesh Council of Scientific \\ and Industrial Research (BCSIR) Laboratories, Dhaka, Bangladesh
}

Correspondence should be addressed to Mohammad Zahangeer Alam; mohammad.alam@wsu.edu

Received 8 April 2017; Revised 11 July 2017; Accepted 7 August 2017; Published 27 September 2017

Academic Editor: Jesús Lozano

Copyright ( 2017 Mohammad Zahangeer Alam et al. This is an open access article distributed under the Creative Commons Attribution License, which permits unrestricted use, distribution, and reproduction in any medium, provided the original work is properly cited.

\begin{abstract}
Salinity has caused significant negative effects on agricultural production. This research is focused on the vulnerabilities of soil and water salinities on crop, fish, and livestock production across the Kalapara coastal belt of Bangladesh. Several parameters were measured as indicators of salinity. The electrical conductivity of water was found to be significant with $\mathrm{TDS}^{-} \mathrm{F}^{-}, \mathrm{Cl}^{-}, \mathrm{SO}_{4}{ }^{2-}$, $\mathrm{Na}^{+}, \mathrm{K}^{+}, \mathrm{Ca}^{2+}, \mathrm{Mg}^{2+}, \mathrm{NO}_{2}{ }^{-}$, and $\mathrm{PO}_{4}{ }^{3-}$. Chloride was found to be identical with $\mathrm{SO}_{4}{ }^{2-}, \mathrm{Na}^{+}, \mathrm{K}^{+}, \mathrm{Ca}^{2+}, \mathrm{Mg}^{2+}, \mathrm{Br}^{-}$, and $\mathrm{PO}_{4}{ }^{3-}$. Electrical conductivity, $\mathrm{F}^{-}, \mathrm{Cl}^{-}, \mathrm{SO}_{4}{ }^{2-}, \mathrm{Na}^{+}, \mathrm{K}^{+}$, and $\mathrm{Mg}^{2+}$ were all found to be higher than the recommended values. Similarly, soil conductivity was found significant with TDS, $\mathrm{Cl}^{-}, \mathrm{SO}_{4}{ }^{2-}, \mathrm{Na}^{+}, \mathrm{F}^{-}, \mathrm{NO}_{2}{ }^{-}, \mathrm{NO}_{3}{ }^{-}$, and $\mathrm{PO}_{4}{ }^{3-}$. Chloride in soil samples was found statistically identical with $\mathrm{SO}_{4}{ }^{2-}, \mathrm{Na}^{+}, \mathrm{NO}_{3}{ }^{-}$, and $\mathrm{PO}_{4}{ }^{3-}$. About 200 ha fodder crops areas are affected each year due to salinity. Ninety-two percent of the areas were found to be salinity affected in the 36 current cropping patterns. Twelve percent of marine fish and 25 percent of shrimp species have disappeared as a result of salinity. The negative impact of soil and water salinity on crops, fish, and livestock has been increasing in this coastal belt.
\end{abstract}

\section{Introduction}

Salinity intrusion is one of the major environmental issues throughout the world [1]. Bangladesh is a growing and developing country. This development is dependent on an agricultural production system which in turn brings economic visibility throughout the world. Salinity issues constrain both the agricultural and economic development. Salinity causes a hostile environment for the normal crop production throughout the year in the coastal belt of Bangladesh. The organic matter content of the coastal soils is pretty low (1.0-1.5\%). Nutrient deficiencies of $\mathrm{N}$ and $\mathrm{P}$ are quite common in saline soils. Micronutrients such as $\mathrm{Cu}$ and $\mathrm{Zn}$ are both widespread. As a result, the reduction of food crop production in the coastal region has significant impact on the national economy of Bangladesh [2]. This threat is elevated because of the reduction of fresh water flow from upstream tidal flow and groundwater discharge [3]. The coastal belt of Bangladesh consists of 19 districts, which cover $32 \%$ of the country and accommodate more than 35 million people [4]. During 1973, salinity affected 83.3 million hectares of land; this was increased to 102 million hectares by the year 2000. After that, salinity affected a recorded 105.6 million hectares during 2009 [5]. Among these affected areas, around 2.5 million hectares of low-lying coastal lands represents 0.9 to 2.1 salinity level (SL) in Bangladesh $[2,6]$. Over the last 35 
years, salinity has increased around 26 percent in the coastal region of Bangladesh [7].

The Kalapara coastal belt is one of the nearest areas to the Bay of Bengal in Bangladesh. This bay is one of the greatest sources of saline water. The electrical conductivity is an indicator of this saline water [8]. This conductivity increases the salt in soil and water across the coastal belt in Bangladesh. This salt water from the Bay of Bengal increases many ions in the soil and water in this coastal region such as chloride $\left(\mathrm{Cl}^{-}\right)$, sulfate $\left(\mathrm{SO}_{4}{ }^{2-}\right)$, sodium $\left(\mathrm{Na}^{+}\right)$, potassium $\left(\mathrm{K}^{+}\right)$, calcium $\left(\mathrm{Ca}^{2+}\right)$, magnesium $\left(\mathrm{Mg}^{2+}\right)$, bromide $\left(\mathrm{Br}^{-}\right)$, phosphate $\left(\mathrm{PO}_{4}{ }^{3-}\right)$, nitrite $\left(\mathrm{NO}_{2}{ }^{-}\right)$, nitrate $\left(\mathrm{NO}_{3}{ }^{-}\right)$, and sulfate $\left(\mathrm{SO}_{4}{ }^{2-}\right)$. More than $99 \%$ of these ions are found in the sea water throughout the world [8]. The adverse impact of this saltwater intrusion is higher in this coastal belt than in any other part of Bangladesh. As a consequence of tropical cyclones, salinity intrusion has been gradually extended toward the inland water and soil [7]. Due to increasing soil and water salinity, people in the communities of the Kalapara coastal regions have been suffering from a scarcity of safe water for the production of crops, fish, and livestock [9]. As a result, soil and water salinity are considered a major constraint to agricultural production and diversity of fish in the coastal areas of this country $[9,10]$.

Agricultural production has contributed $21 \%$ of the national GDP of Bangladesh [14]. The majority of people living in the coastal community are dependent on the agricultural production of crops, fish, and livestock. Several climatic factors such as temperature, wind speed, and rainfall in the coastal zone are favorable for a wide range of food crops [15]. For example, cereals, pulses, vegetables, fruits, and cash crops have been cultivated successfully for many decades [16]. For this reason, planning for cropping patterns with the selection of appropriate varieties that have salinity tolerance is necessary for the local environment [17]. For instance, monsoon season (June to October) is favorable for the cultivation of crops due to the low salinity intrusion [18]. However, as soil salinity increases each year, dry season (November and May) is only favorable for the cultivation of Rabi (December-February) crops. In fact, dry-season agriculture is particularly difficult in Bangladesh due to high salt stress across the coastal belt. For this reason, crop production has been negatively affected each year for many decades across the coastal belt of Bangladesh [19].

Surface water and groundwater are both connected to major rivers along the coastal belt through various estuaries and water inlets $[20,21]$. These sources of water are contaminated by salinity which is influenced by rainfall, river flows, upstream withdrawal of water, and sea level rising [22]. Since 1948, salinity of rivers in the southern districts of Patuakhali, Pirojpur, Barguna, Satkhira, Bagerhat, and Khulna has risen by 45\% [23]. However, coastal people of Bangladesh rely heavily on rivers for fish, tube wells (groundwater), and ponds for washing, bathing, and drinking [24]. Also, domestic ponds cover $10 \%$ of the total land area which is mixed with saline water from rivers, soil runoff, and shallow groundwater [22]. Approximately 20 million people are affected by unpredictable degrees of salinity in the water along the coastal region of Bangladesh [25].

Due to increased salinity there is a shortage of grazing land and fodder crops for livestock production. Because of this, communities must utilize other natural resources to make up for the lack of protein from livestock. This shortage of milk and cattle in the coastal areas is also documented in other studies [26]. The reduced ability for cattle-raising in Bangladesh has had serious economic and nutritional consequences, especially for the children [27]. However, people have also converted fresh water areas through intrusion of saline water for shrimp culture, increasing the salinity in the surrounding areas and damaging the grazing areas of livestock. These kinds of agrobiodiversity changes have caused reduced frequency of consumption of livestock, crops, and fish across the coastal belt in Bangladesh. These changes in food habits might also lead to considerable negative consequences for agricultural production systems for the rural populations across the coastal belt of Bangladesh [28].

In addition, saline water has been increasing across the coastal belt due to the intensity of cyclones in Bangladesh. This saline water has many connections with fresh water bodies across the coastal belt. It leads to changes in the trophic structure and diversity of shallow fresh water bodies such as increased strength of trophic interactions. As a result, saline water fish are mixed with fresh water species. Because of this, the intrusion of saline water in different fresh water bodies has played a significant role in the disappearance of some fish species [29].

There are not currently any established guidelines for salinity levels in agricultural production systems in Bangladesh [30]. High salinity levels might have numerous direct and indirect impacts on crops, livestock, and fish. Due to the connectivity of agricultural products with human livelihood, greater levels of gestational hypertension were found in pregnant women in the southwestern coast of Bangladesh, compared with noncoastal pregnant women. This was hypothesized to be caused by saline water and agricultural crops [31,32]. In this situation, management of salinity intrusion is the vital issue for Bangladesh. However, salinity in the water and soil may be reduced in ways such as coastal embankment projects, construction of dam and sluices, zoning of coastal salinity areas, a plantation program, selection of salinity tolerance cultivars, and public awareness programs that can contribute to the mission toward sustainable livelihood in the coastal region of Bangladesh [10]. This study documents the current status of soil and water salinities across the coastal belt and their possible impacts on agriculture. It is hypothesized that regular monitoring of soil and water salinity levels will be of significant help in the protection of crops, fisheries, and livestock along the coastal belt of Bangladesh.

\section{Materials and Methods}

2.1. Description of Study Areas. Kalapara Upazila is the most salinity prone area in the southwestern part of Bangladesh. It is adjacent to the Amtali Upazila of Barguna district on the north, the Bay of Bengal on the south, and Rabnabad 
TABLE 1: Geographical position for water and soil sampling study areas across the coastal belt.

\begin{tabular}{|c|c|c|c|}
\hline Samples & Locations & Latitude & Longitude \\
\hline \multirow{12}{*}{ Water } & Ander manik river & $21^{\circ} 53.67933^{\prime}$ & $90^{\circ} 8.36508^{\prime}$ \\
\hline & Shibbaria river & $21^{\circ} 51.26377^{\prime}$ & $90^{\circ} 7.52335^{\prime}$ \\
\hline & Badurtoli Canal & $21^{\circ} 54.66933^{\prime}$ & $90^{\circ} 8.36548^{\prime}$ \\
\hline & Char Gangamoti (beach area) & $21^{\circ} 48.24381^{\prime}$ & $90^{\circ} 12.23918^{\prime}$ \\
\hline & Kuakata beach (left) & $21^{\circ} 48.81624^{\prime}$ & $90^{\circ} 7.30991^{\prime}$ \\
\hline & Kuakata beach (right) & $21^{\circ} 48.81645^{\prime}$ & $90^{\circ} 7.30976^{\prime}$ \\
\hline & Char Gangamoti Mangrove & $21^{\circ} 49.24878^{\prime}$ & $90^{\circ} 12.7492^{\prime}$ \\
\hline & Sonatula River & $21^{\circ} 53.67948^{\prime}$ & $90^{\circ} 8.36345^{\prime}$ \\
\hline & ShantiBagh Canal & $21^{\circ} 53.3578^{\prime}$ & $90^{\circ} 8.4617^{\prime}$ \\
\hline & Paira river & $22^{\circ} 27.79685^{\prime}$ & $90^{\circ} 20.47599^{\prime}$ \\
\hline & Kalapara town pond & $21^{\circ} 53.3569^{\prime}$ & $90^{\circ} 8.8653^{\prime}$ \\
\hline & Kalapara town tube well water & $21^{\circ} 53.4689^{\prime}$ & $90^{\circ} 8.8952^{\prime}$ \\
\hline \multirow{6}{*}{ Soil } & Mustafapur Nilgonj & $21^{\circ} 56.07547^{\prime}$ & $90^{\circ} 9.912^{\prime}$ \\
\hline & Char Gangamoti (beach area) & $21^{\circ} 48.43599^{\prime}$ & $90^{\circ} 12.3969^{\prime}$ \\
\hline & Kuakata beach (left) & $21^{\circ} 48.81624^{\prime}$ & $90^{\circ} 7.30991^{\prime}$ \\
\hline & Kuakata beach (right) & $21^{\circ} 48.81645^{\prime}$ & $90^{\circ} 7.30976^{\prime}$ \\
\hline & Char Gangamoti Mangrove & $21^{\circ} 49.24878^{\prime}$ & $90^{\circ} 12.7492^{\prime}$ \\
\hline & Niamatpur & $21^{\circ} 57.92477^{\prime}$ & $90^{\circ} 11.97595^{\prime}$ \\
\hline
\end{tabular}

channel and Galachipa Upazila on the east. The total area of Kalapara Upazila is 491 square kilometers and the population is 238,000 [33]. Water samples were collected from 12 locations of the Kalapara coastal belt. These areas are Ander manik river, Shibbaria river, Badurtoli Canal, Char Gangamoti (Beach area), Kuakata beach (left), Kuakata beach (right), Char Gangamoti Mangrove, Sonatula River, ShantiBagh Canal, Paira river, Kalapara town pond, and Kalapara town tube well water. Soil samples were also collected from Mustafapur nilgonj, Char Gangamoti (Beach area), Kuakata beach (left), Kuakata beach (right), Char Gangamoti Mangrove, and Niamatpur areas of Kalapara coastal belt of Bangladesh. Geographical Positioning System (GPS) of study areas is shown in Table 1. The study area on a Bangladesh map and sampling locations of these study areas are highlighted in Figures 1 and 2, respectively.

2.2. Inception Meeting. An inception meeting was arranged at the Department of Agricultural Extension (DAE) in the Kalapara Upazila area of the coastal belt for 3 days. This meeting was conducted with government officials, fishermen, visitors, and farmers who have been living in the Kalapara Upazila area. This meeting was conducted to discuss the soil and water salinities and their possible effects on crops, fish, and livestock. During this meeting, participants contributed their unique perspectives regarding soil and water salinity and the possible impacts upon crops, livestock, and fish. Based on this meeting, we were able to identify the major areas affected by salinity at Kalapara coastal belt for the collection of soil and water samples.

2.3. Collection of Water Samples. Water samples were collected randomly with different salinities along the coastal belt at Kalapara Upazila for analysis of salinity indicators in 2016. Distance of each collected water sample for a location was 50 meters; three collected water samples were mixed together for making a sample for each location. Samples were collected in 100-500 ml polyethylene plastic bottles. Each bottle was cleaned thoroughly by rinsing with diluted $\mathrm{HCl}$ followed by washing with distilled water [34]. The water samples were filtered with Whatman 42 to remove suspended solids. Prepared sample solutions were sealed immediately to minimize exposure to air, and collected samples were carried to the Laboratory of Environmental Science of BSMRAU and Bangladesh Council of Scientific and Industrial Research (BCSIR) in Dhaka for analysis of dissolved ions and other water quality constituents. All of the collected water samples were kept at $4^{\circ} \mathrm{C}$ refrigerator temperature before the analysis of the chemical parameters was completed.

2.4. Collection of Soil Samples. Soil samples were collected from different areas affected by salinity on the coastal belt at Kalapara Upazila for the analysis of chemical properties. Soil samples were collected by Auger from different locations randomly. Distance of each collected soil sample was about 15 meters for a location; four collected soil samples were mixed together for making a sample for each location. All collected samples were kept in polyethylene zip lock bags through proper marking. Then samples were carried into the Laboratory of Environmental Science at Bangabandhu Sheikh Mujibur Rahman Agricultural University (BSMRAU) and Bangladesh Council of Scientific and Industrial Research (BCSIR) in Dhaka for analysis of chemical properties. All soil samples were preserved at room temperature in the laboratory before the analysis of the chemical parameters was completed.

2.5. Determination of Water Chemical Properties. Water $\mathrm{pH}$ was determined with a glass electrode $\mathrm{pH}$ meter (Model: Metrohm 906 Titrande) [35]. The electrical conductivity (EC) 


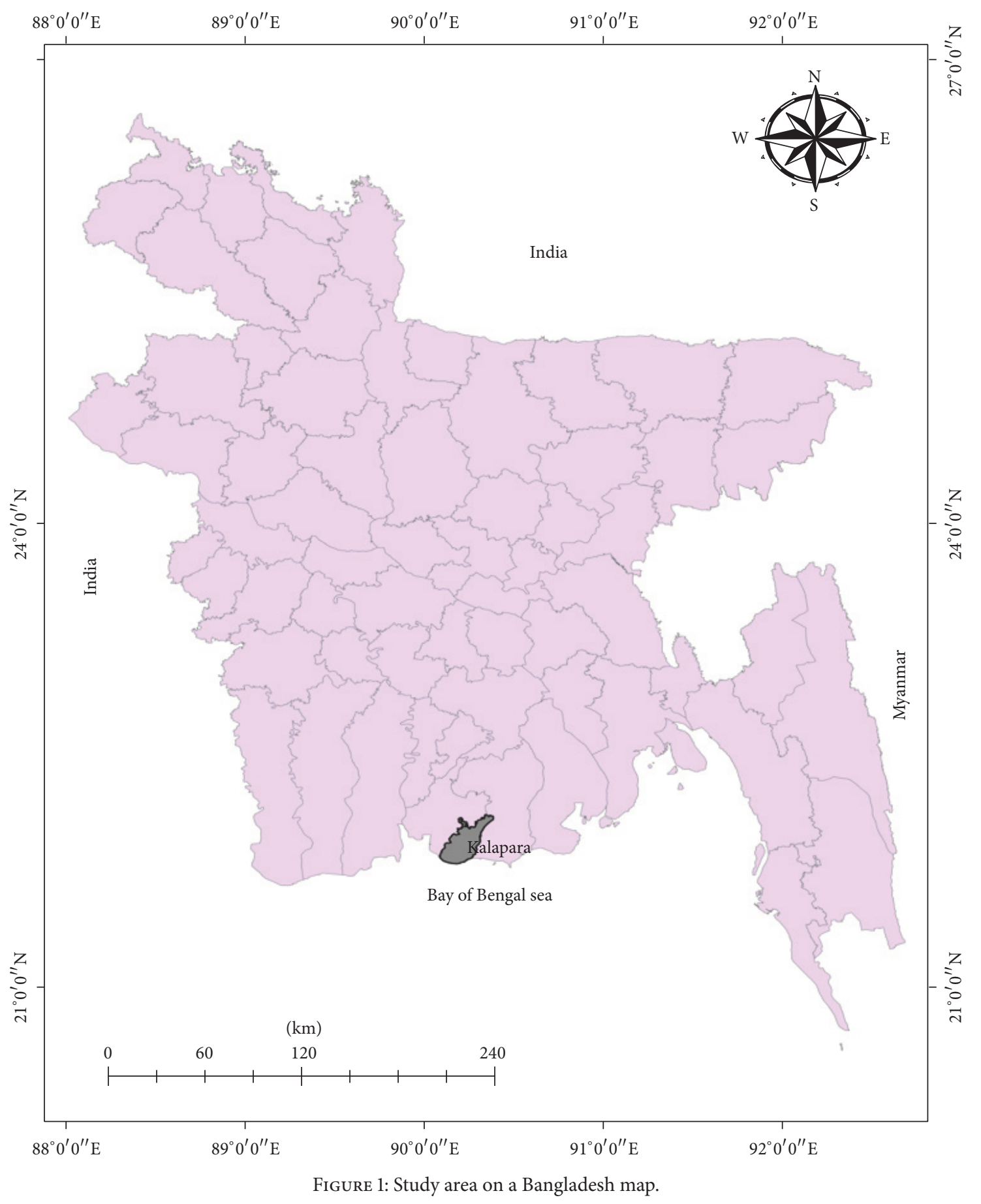

was analyzed during sample collection with a conductivity meter (Model: HANNA HI-8633) [35]. Total dissolved solids (TDS) were determined with a TDS meter (Model: $\mathrm{HACH}$ SensION 156) [36]. The salinity was measured with a salinity meter (Model: HACH SensION 156) [36].

Anions like fluoride $\left(\mathrm{F}^{-}\right)$, chloride $\left(\mathrm{Cl}^{-}\right)$, nitrite $\left(\mathrm{NO}_{2}{ }^{-}\right)$, bromide $\left(\mathrm{Br}^{-}\right)$, nitrate $\left(\mathrm{NO}_{3}{ }^{-}\right)$, phosphate $\left(\mathrm{PO}_{4}{ }^{3-}\right)$, and sulfate $\left(\mathrm{SO}_{4}{ }^{2-}\right)$ were determined by ion chromatography (Model: Dionex ICS-1600) followed by APHA 4110 method [37]. Sodium $\left(\mathrm{Na}^{+}\right)$and potassium $\left(\mathrm{K}^{+}\right)$of water samples were determined by flame emission spectrophotometry (Model: Jenway, PFP7) at $589 \mathrm{~nm}$ and $769 \mathrm{~nm}$ wavelength, respectively [35]. Calcium $\left(\mathrm{Ca}^{2+}\right)$ and magnesium $\left(\mathrm{Mg}^{2+}\right)$ in water samples were determined with an atomic absorption spectrophotometer (AAS) (Model: AA-7000, Shimadzu) followed by APHA 3111, which was calibrated using certified reference materials (CRMs) [37] (Table 2). 


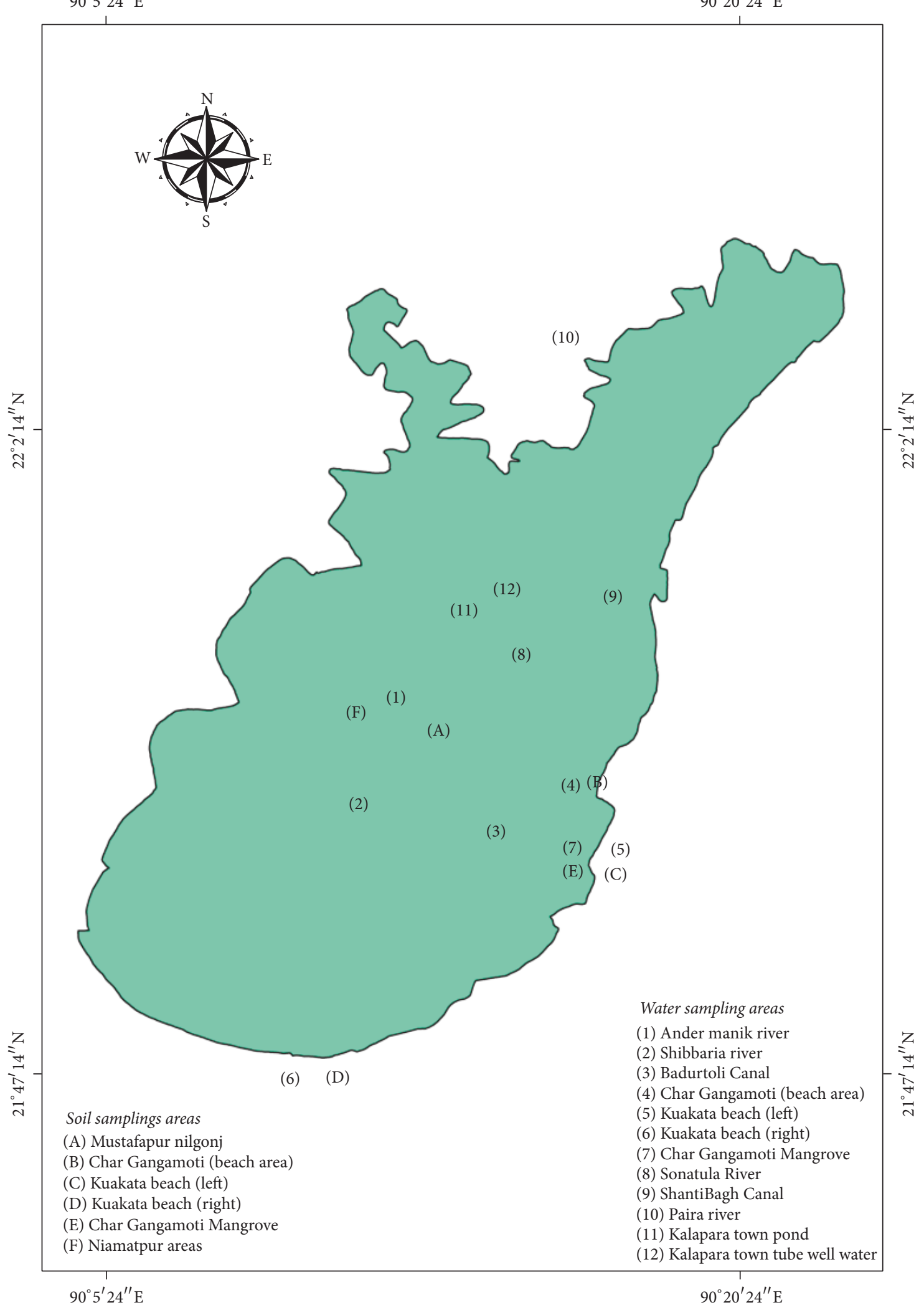

FIGURE 2: Sampling locations in the study area. 
TABLE 2: Methods for the determination of salinity indicators in soil and water samples across the Kalapara coastal belt in Bangladesh.

\begin{tabular}{|c|c|c|}
\hline Samples & Chemical properties & Methods/instrument for chemical analysis \\
\hline \multirow{15}{*}{ Water } & Salinity \% & Salinity meter (Model: HACH SensION 156) \\
\hline & Conductivity $(\mu \mathrm{S} / \mathrm{cm})$ & Conductivity meter (Model: HANNA HI-8633) \\
\hline & TDS, mg/l & TDS meter (Model: HACH SensION 156) \\
\hline & $\mathrm{pH}$ & Glass electrode pH meter (Model: Metrohm 906 Titrande) \\
\hline & Fluoride $\left(\mathrm{F}^{-}\right), \mathrm{mg} / \mathrm{l}$ & Ion chromatography (Model: Dionex ICS-1600) \\
\hline & Chloride $\left(\mathrm{Cl}^{-}\right), \mathrm{mg} / \mathrm{l}$ & Ion chromatography (Model: Dionex ICS-1600) \\
\hline & Nitrite $\left(\mathrm{NO}_{2}^{-}\right), \mathrm{mg} / \mathrm{l}$ & Ion chromatography (Model: Dionex ICS-1600) \\
\hline & Bromide $\left(\mathrm{Br}^{-}\right), \mathrm{mg} / \mathrm{l}$ & Ion chromatography (Model: Dionex ICS-1600) \\
\hline & Nitrate $\left(\mathrm{NO}_{3}{ }^{-}\right), \mathrm{mg} / \mathrm{l}$ & Ion chromatography (Model: Dionex ICS-1600) \\
\hline & Phosphate $\left(\mathrm{PO}_{4}{ }^{3-}\right), \mathrm{mg} / \mathrm{l}$ & Ion chromatography (Model: Dionex ICS-1600) \\
\hline & Sulfate $\left(\mathrm{SO}_{4}{ }^{2-}\right), \mathrm{mg} / \mathrm{l}$ & Ion chromatography (Model: Dionex ICS-1600) \\
\hline & Sodium $\left(\mathrm{Na}^{+}\right), \mathrm{mg} / \mathrm{l}$ & Flame emission spectrophotometry (Model: Jenway, PFP7) \\
\hline & Potassium $\left(\mathrm{K}^{+}\right), \mathrm{mg} / \mathrm{l}$ & Flame emission spectrophotometry (Model: Jenway, PFP7) \\
\hline & Calcium $\left(\mathrm{Ca}^{2+}\right), \mathrm{mg} / \mathrm{l}$ & Atomic Absorption Spectrophotometer (AAS) (Model: AA-7000, Shimadzu) \\
\hline & Magnesium $\left(\mathrm{Mg}^{2+}\right), \mathrm{mg} / \mathrm{l}$ & Atomic Absorption Spectrophotometer (AAS) (Model: AA-7000, Shimadzu) \\
\hline \multirow{15}{*}{ Soil } & $\mathrm{pH}$ & Glass electrode $\mathrm{pH}$ meter \\
\hline & TDS, g/kg & TDS meter \\
\hline & Conductivity $(\mathrm{mS} / \mathrm{cm})$ & Conductivity meter (Model: HACH SensION 156) \\
\hline & Salinity \% & Salinity meter (Model: DDSJ-308A) \\
\hline & Fluoride $\left(\mathrm{F}^{-}\right), \mathrm{mg} / \mathrm{kg}$ & Ion chromatography (Model: Dionex ICS-1600) \\
\hline & Chloride $\left(\mathrm{Cl}^{-}\right), \mathrm{mg} / \mathrm{kg}$ & Ion chromatography (Model: Dionex ICS-1600) \\
\hline & Nitrite $\left(\mathrm{NO}_{2}^{-}\right), \mathrm{mg} / \mathrm{kg}$ & Ion chromatography (Model: Dionex ICS-1600) \\
\hline & Bromide $\left(\mathrm{Br}^{-}\right), \mathrm{mg} / \mathrm{kg}$ & Ion chromatography (Model: Dionex ICS-1600) \\
\hline & Nitrate $\left(\mathrm{NO}_{3}{ }^{-}\right), \mathrm{mg} / \mathrm{kg}$ & Ion chromatography (Model: Dionex ICS-1600) \\
\hline & Phosphate $\left(\mathrm{PO}_{4}{ }^{3-}\right), \mathrm{mg} / \mathrm{kg}$ & Vanadomolybdophosphoric yellow color method \\
\hline & Sulfate $\left(\mathrm{SO}_{4}{ }^{2-}\right), \mathrm{mg} / \mathrm{kg}$ & Turbidimetric method \\
\hline & Sodium $\left(\mathrm{Na}^{+}\right), \mathrm{mg} / \mathrm{kg}$ & Flame emission spectrophotometer (Model: Jenway, PFP7) \\
\hline & Potassium $\left(\mathrm{K}^{+}\right), \mathrm{mg} / \mathrm{kg}$ & Flame emission spectrophotometer (Model: Jenway, PFP7) \\
\hline & Calcium $\left(\mathrm{Ca}^{2+}\right), \mathrm{mg} / \mathrm{kg}$ & Atomic Absorption Spectrophotometer (Model: AA-7000, Shimadzu) \\
\hline & Magnesium $\left(\mathrm{mg}^{2+}\right), \mathrm{mg} / \mathrm{kg}$ & Atomic Absorption Spectrophotometer (Model: AA-7000, Shimadzu) \\
\hline
\end{tabular}

2.6. Detection of Soil Chemical Properties. Soil $\mathrm{pH}$ was analyzed with a glass electrode $\mathrm{pH}$ meter [35]. The electrical conductivity (EC) was examined with a conductivity meter (Model: HACH SensION 156) [38]. Total dissolved solids (TDS) were detected with a TDS meter [38]. The salinity was measured with a salinity meter (Model: DDSJ308A) [36]. The chloride $\left(\mathrm{Cl}^{-}\right)$, bromide $\left(\mathrm{Br}^{-}\right)$, fluoride $\left(\mathrm{F}^{-}\right)$, nitrite $\left(\mathrm{NO}_{2}{ }^{-}\right)$, and nitrate $\left(\mathrm{NO}_{3}{ }^{-}\right)$were determined by ion chromatography (Model: Dionex ICS-1600) followed by APHA 4110 method [37]. Sodium $\left(\mathrm{Na}^{+}\right)$and potassium $\left(\mathrm{K}^{+}\right)$ of soil samples were determined with the flame emission spectrophotometer (Model: Jenway, PFP7) at $589 \mathrm{~nm}$ and $769 \mathrm{~nm}$ wavelength, respectively [35]. The sulfate $\left(\mathrm{SO}_{4}{ }^{2-}\right)$ content of soil samples was determined by turbidimetric method [39]. Phosphate $\left(\mathrm{PO}_{4}{ }^{3-}\right)$ content of the soil samples was determined by vanadomolybdophosphoric yellow color method [35]. Calcium $\left(\mathrm{Ca}^{2+}\right)$ and magnesium $\left(\mathrm{Mg}^{2+}\right)$ in soil samples were determined by an atomic absorption spectrophotometer using certified reference material (CRMs) [38] (Table 2).
2.7. Quality Control. Quality control (QC) monitors reagent quality, apparatus cleaning, and accuracy and precision of methods and instrumentation and reliability were implemented daily in the laboratory. Under this QC, blank analysis, replication, internal standard, and certified reference materials were followed properly for each collected soil and water sample for the measurement of salinity indicators. During ion analysis, standard curve was prepared for each single anion at three points of concentration using certified reference material. For every five samples, a reference sample and spiked sample were included to ensure the QC. Ion chromatography, flame photometer, and atomic absorption spectrophotometer were calibrated for every six months and methods of analysis were validated by Bangladesh Accreditation Board (BAB) as per ISO/IEC 17025. All quality assurance was maintained according to the proposed guidelines of American Public Health Association (APHA) [40], National Association of Testing Authorities (NATA) [41], and National Environment Protection Measure (NEPM) [42]. According to their guidelines, several QC parameters are highlighted in Tables 3 and 4 . 


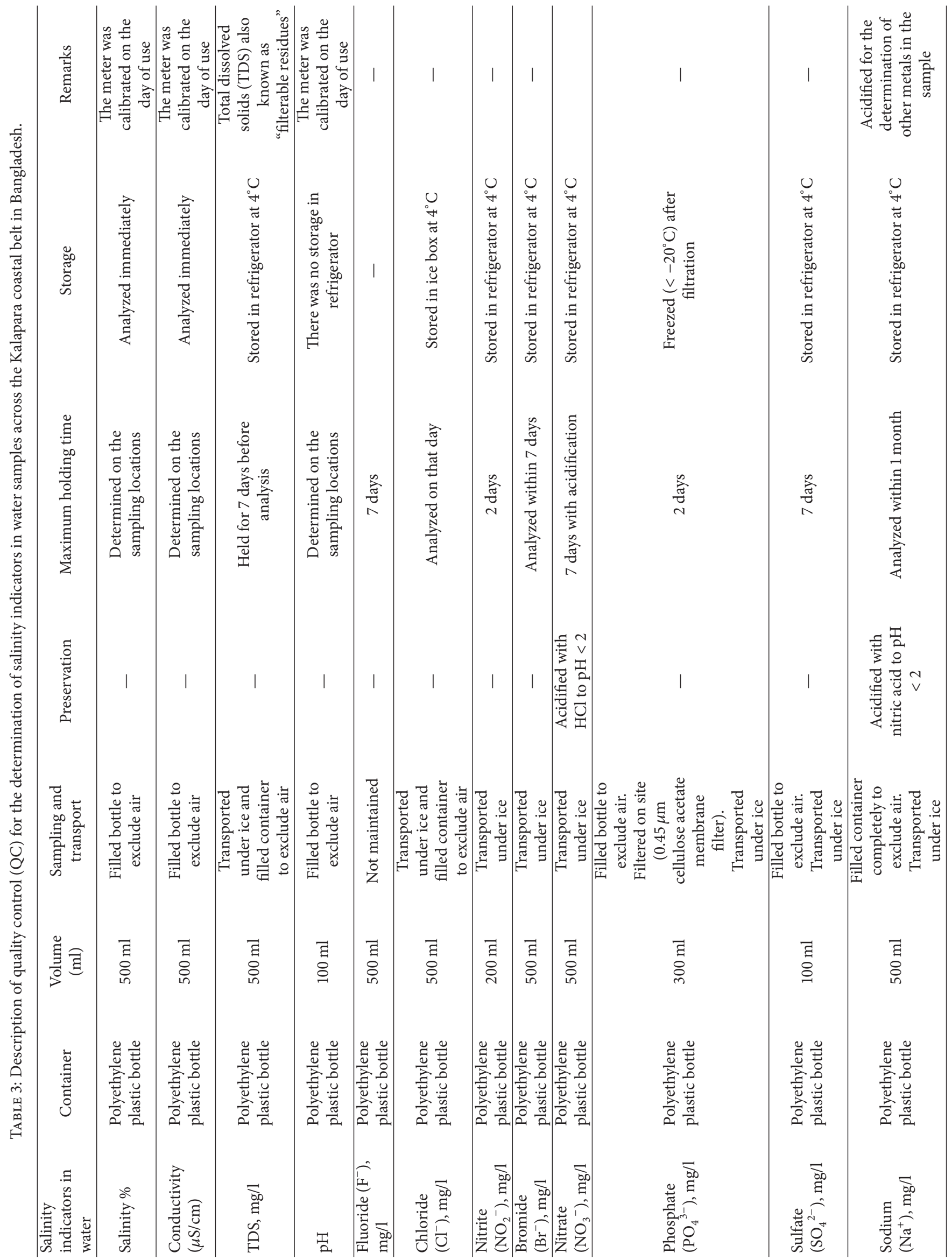




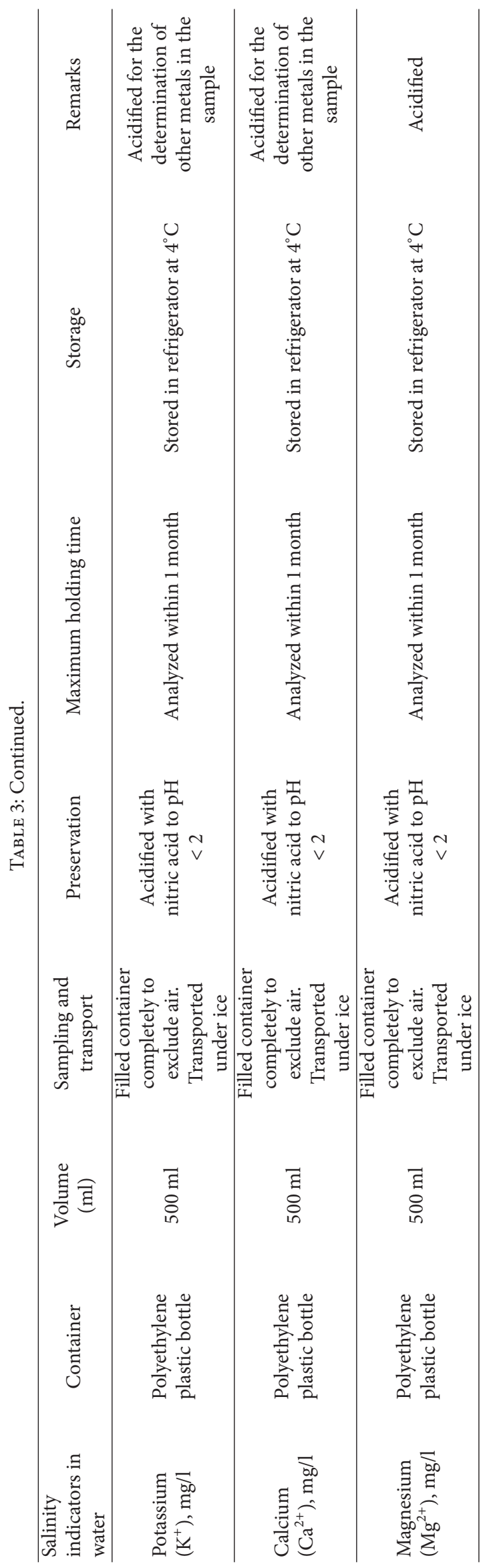


TABLE 4: Description of quality control (QC) for the determination of salinity indicators in soil samples across the Kalapara coastal belt in Bangladesh.

\begin{tabular}{|c|c|c|c|c|c|}
\hline Chemical properties & Container & $\begin{array}{c}\text { Sampling \& } \\
\text { transport }\end{array}$ & $\begin{array}{c}\text { Maximum } \\
\text { holding time }\end{array}$ & Storage & Comments \\
\hline $\begin{array}{l}\text { Salinity \% } \\
\text { Conductivity }(\mathrm{mS} / \mathrm{cm}) \\
\text { TDS, g/kg } \\
\text { pH } \\
\text { Fluoride }\left(\mathrm{F}^{-}\right), \mathrm{mg} / \mathrm{kg} \\
\text { Chloride }\left(\mathrm{Cl}^{-}\right), \mathrm{mg} / \mathrm{kg} \\
\text { Nitrite }\left(\mathrm{NO}_{2}^{-}\right), \mathrm{mg} / \mathrm{kg} \\
\text { Bromide }\left(\mathrm{Br}^{-}\right), \mathrm{mg} / \mathrm{kg} \\
\text { Nitrate }\left(\mathrm{NO}_{3}^{-}\right), \mathrm{mg} / \mathrm{kg} \\
\text { Phosphate }\left(\mathrm{PO}_{4}{ }^{3-}\right), \mathrm{mg} / \mathrm{kg} \\
\text { Sulfate }\left(\mathrm{SO}_{4}{ }^{2-}\right), \mathrm{mg} / \mathrm{kg} \\
\text { Sodium }\left(\mathrm{Na}^{+}\right), \mathrm{mg} / \mathrm{kg} \\
\text { Potassium }\left(\mathrm{K}^{+}\right), \mathrm{mg} / \mathrm{kg} \\
\text { Calcium }\left(\mathrm{Ca}^{2+}\right), \mathrm{mg} / \mathrm{kg} \\
\text { Magnesium }\left(\mathrm{Mg}^{2+}\right), \mathrm{mg} / \mathrm{kg}\end{array}$ & $\begin{array}{l}\text { Polyethylene zip } \\
\text { lock bag }\end{array}$ & $\begin{array}{l}\text { Transported } \\
\text { under ice box }\end{array}$ & 7 days & $\begin{array}{c}\text { Stored in } \\
\text { refrigerator at } \\
4^{\circ} \mathrm{C}\end{array}$ & $\begin{array}{l}\text { Field moist or air } \\
\text { dried soil }\end{array}$ \\
\hline
\end{tabular}

2.8. Data Collection regarding Salinity Affected Cropping and Livestock's Grazing Areas. Based on the inception meeting, data on salinity affected cropping areas was collected from the Department of Agricultural Extension (DAE) at Kalapara Upazila. Information regarding salinity intrusion on cropping patterns was also gathered from these studies. This data was verified in the discussion with a group of 25 farmers from different cropping areas at Kalapara Upazila with the help of DAE personnel. On the other hand, data pertaining to salinity affected fodder crops for livestock production was collected from the Department of Livestock Services (DLS) at Kalapara Upazila. Similarly, this information was also justified by discussions with the affected livestock farmers from the coastal belt of Kalapara (Tables 8 and 9).

2.9. Information regarding Fish Biodiversity. Based on the inception meeting, information regarding the number of salinity affected fresh water bodies was noted from the Department of Fisheries (DOF) at Kalapara Upazila. Based on the primary information from DoF, we interviewed a group of people who have been living in the surrounding areas of each of the affected water bodies to get data regarding visible, threatened, endangered, and extinct fish species. We interviewed 50 people from each location; among these, an average of 10-12 were women and the rest were men. They were on average 40-60 years old. The interviewees were involved in diverse professions such as fishing, boating, farming, government officials, and researchers. All recorded information regarding the current status of biological diversity of fish is presented in Tables 10 and 11.

2.10. Statistical Analysis. Soil and water quality constituents were analyzed through Pearson correlation coefficient using "R" Software, version 3.2.2 (R Foundation for Statistical Computing, Vienna, Austria). Significant levels of correlation between soil and water quality parameters were analyzed for the validation of the data using " $R$ " Software, version 3.2.2 (R Foundation for Statistical Computing, Vienna, Austria).

\section{Results}

3.1. Chemical Properties of Water. The percentage of salinity in water was significantly correlated with conductivity, total dissolved solid (TDS), chloride $\left(\mathrm{Cl}^{-}\right)$, sulfate $\left(\mathrm{SO}_{4}{ }^{2-}\right)$, sodium $\left(\mathrm{Na}^{+}\right)$, potassium $\left(\mathrm{K}^{+}\right)$, calcium $\left(\mathrm{Ca}^{2+}\right)$, magnesium $\left(\mathrm{Mg}^{2+}\right)$ $(p \leq 0.01)$, bromide $\left(\mathrm{Br}^{-}\right)(p \leq 0.1)$, and phosphate $\left(\mathrm{PO}_{4}{ }^{3-}\right)(p \leq 0.05)$. The conductivity was found statistically significant with TDS, $\mathrm{F}^{-}, \mathrm{Cl}^{-}, \mathrm{SO}_{4}{ }^{2-}, \mathrm{Na}^{+}, \mathrm{K}^{+}, \mathrm{Ca}^{2+}, \mathrm{Mg}^{2+}$ $(p \leq 0.01), \mathrm{NO}_{2}{ }^{-}(p \leq 0.1)$, and $\mathrm{PO}_{4}{ }^{3-}(p \leq 0.05)$. Water $\mathrm{pH}$ was correlated with $\mathrm{F}^{-}(p \leq 0.1)$. Similarly, chloride was found statistically identical with $\mathrm{SO}_{4}{ }^{2-}, \mathrm{Na}^{+}, \mathrm{K}^{+}, \mathrm{Ca}^{2+}$, $\mathrm{Mg}^{2+}(p \leq 0.01), \mathrm{Br}^{-}(p \leq 0.1)$, and $\mathrm{PO}_{4}{ }^{3-}(p \leq 0.05)$. The bromide $\left(\mathrm{Br}^{-}\right)$was positively correlated with $\mathrm{SO}_{4}{ }^{2-}, \mathrm{Na}^{+}$, $\mathrm{Ca}^{2+}(p \leq 0.1)$, and $\mathrm{Mg}^{2+}(p \leq 0.01)$. The phosphate $\left(\mathrm{PO}_{4}{ }^{3-}\right)$ was found to have significant correlation with $\mathrm{SO}_{4}{ }^{2-}, \mathrm{Na}^{+}$, $\mathrm{K}^{+}, \mathrm{Ca}^{2+}$, and $\mathrm{Mg}^{2+}(p \leq 0.05)$. The sulfate was found to have a significant relationship with $\mathrm{Na}^{+}, \mathrm{K}^{+}, \mathrm{Ca}^{2+}$, and $\mathrm{Mg}^{2+}$ $(p \leq 0.05)$. Sodium was also significantly different from $\mathrm{K}^{+}, \mathrm{Ca}^{2+}$, and $\mathrm{Mg}^{2+}(p \leq 0.01)$. Potassium was positively correlated with $\mathrm{Ca}^{2+}$ and $\mathrm{Mg}^{2+}(p \leq 0.01)$. Calcium was found significantly different from $\mathrm{Mg}^{2+}(p \leq 0.01)$. Several chemical properties of water samples such as conductivity (322.9 $\mu \mathrm{S} / \mathrm{cm}), \mathrm{F}^{-}$(3.65), $\mathrm{Cl}^{-}$(5037.60), $\mathrm{SO}_{4}{ }^{2-}$ (557.34), $\mathrm{Na}^{+}$ (5184.94), $\mathrm{Mg}^{+}$(38.50), and $\mathrm{K}^{+}$(78.89) (mg/l) were found to be higher than the recommended values of conductivity $(300 \mu \mathrm{S} / \mathrm{cm}), \mathrm{F}^{-}$(1-2), $\mathrm{Cl}^{-}$(150-600), $\mathrm{SO}_{4}{ }^{2-}$ (250-400), $\mathrm{Na}^{+}$ (200), $\mathrm{Mg}^{+}$(30-35), and $\mathrm{K}^{+}(12) \mathrm{mg} / \mathrm{l}$ (Tables 5 and 7).

3.2. Chemical Properties of Soils. The soil salinity was significantly correlated with conductivity, $\mathrm{Cl}^{-}, \mathrm{SO}_{4}{ }^{2-}, \mathrm{Na}^{+}(p \leq$ $0.01), \mathrm{F}^{-}, \mathrm{NO}_{2}{ }^{-}, \mathrm{NO}_{3}{ }^{-}$, and $\mathrm{PO}_{4}{ }^{3-}(p \leq 0.1)$. The conductivity was found to be statistically significant with TDS, $\mathrm{Cl}^{-}$, $\mathrm{SO}_{4}{ }^{2-}, \mathrm{Na}^{+},(p \leq 0.01), \mathrm{F}^{-}, \mathrm{NO}_{2}{ }^{-}, \mathrm{NO}_{3}{ }^{-}(p \leq 0.1)$, and $\mathrm{PO}_{4}{ }^{3-}$ $(p \leq 0.05)$. The soil $\mathrm{pH}$ was correlated with $\mathrm{F}^{-}(p \leq 0.1)$. The fluoride was found statistically different from $\mathrm{NO}_{2}{ }^{-}, \mathrm{Br}^{-}$ $(p \leq 0.05)$, and $\mathrm{Cl}^{-}(p \leq 0.1)$. Similarly, chloride was found 


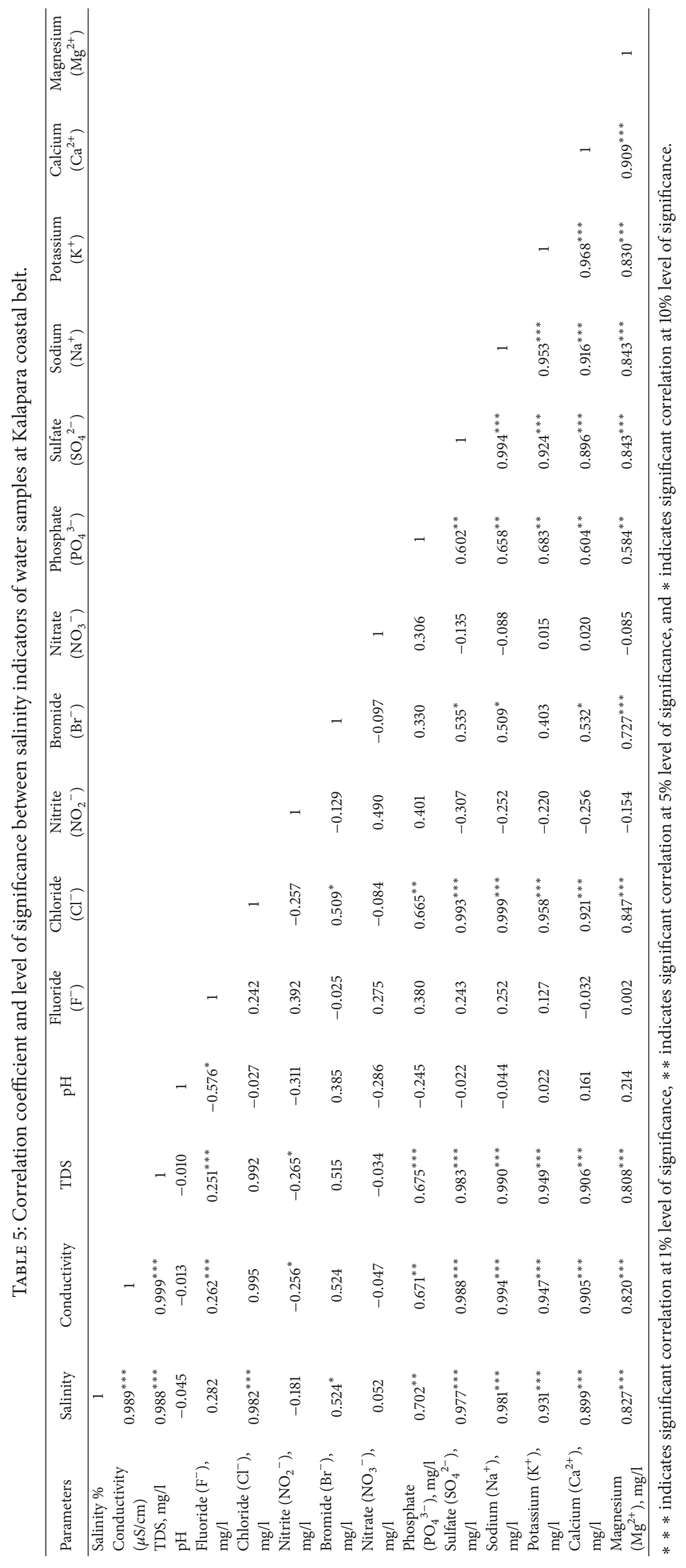


statistically identical with $\mathrm{SO}_{4}{ }^{2-}, \mathrm{Na}^{+}(p \leq 0.01), \mathrm{NO}_{3}{ }^{-}$, and $\mathrm{PO}_{4}{ }^{3-}(p \leq 0.1)$. Nitrite was significantly correlated with $\mathrm{Na}^{+}(p \leq 0.1)$. The bromide was positively correlated with $\mathrm{NO}_{3}{ }^{-}(p \leq 0.01) . \mathrm{SO}_{4}{ }^{2-}$ and $\mathrm{Na}^{+}$both were positively correlated with $\mathrm{PO}_{4}{ }^{3-}(p \leq 0.1) \cdot \mathrm{SO}_{4}{ }^{2-}$ and $\mathrm{Ca}^{2+}$ both were found statistically significant with $\mathrm{Na}^{+}(p \leq 0.01)$ and $\mathrm{Mg}^{2+}$ $(p \leq 0.05)$. The soil conductivity was found to be $6.88 \mathrm{mS} / \mathrm{cm}$, while the recommended value was $0.75-4$ for a sustainable environment (Tables 6 and 7).

3.3. Effect of Salinity on Crops and Livestock Production. We know that farmers are reliant on crop and livestock production across the coastal belt of Kalapara Upazila. Through interviews with community members in the study areas we determined threats that included decreases in crop and livestock production. During Aman season (June to September), $100 \%$ of the areas are covered by crops. About 200 ha fodder crop areas are affected each year due to salinity. For this reason, food shortage is one of the crucial issues for livestock and other animals. Due to the high dependence on the salinity affected fodder crops, livestock are affected by many negative consequences such as diarrhea, skin diseases, liver fluke, loss of body weight, and breakdown of the immune system (Table 8 ). In addition, we found 36 cropping patterns in the 39102 ha cropping area at the Kalapara coastal belt. Among these cropping patterns, 92 percent of these were identified as salinity affected areas (Table 9).

3.4. Effect of Salinity on Fish Species Production. Out of 857 ha water bodies, $2-3 \%$ are occupied by shrimp culture which has contributed to the salinity of inland and fresh water bodies across the coastal belt. Other areas have also been replaced by saline water on the Kalapara coastal belt (Table 8). We found the number of fish species to be 59 inland, 57 marine, 10 exotic, 3 prawns, 4 shrimp, and $4 \mathrm{crab}$ across the Kalapara coastal belt in Bangladesh. Among these fish species, the percentages that were identified as visible, threatened, endangered, and extinct under the category of inland fish species were $45,24,19$, and 12 , respectively. On the other hand, between the marine fish species, the percentages of visible, threatened, endangered, and extinct species were found to be $43,21,24$, and 12 , respectively. None of the exotic, prawn, and crab species were identified in the extinct category. However, 25 percent of the shrimp species were recorded in the extinct category. Natural disasters such as salinity and cyclones were both determined to be critical causes for the extinction of fish species across the coastal belt of Kalapara Upazila (Tables 10 and 11).

\subsection{Discussion of the Findings}

3.5.1. Vulnerabilities of Salinity. Different cations and anions are inconsistent in saline soil and water. The degree of salinity effects on crops, livestock, and water bodies in fish may not have the same level of effects on the environment [43]. Specific ion toxicity occurs most commonly due to excessive boron, $\mathrm{Cl}^{-}, \mathrm{HCO}_{3}{ }^{-}, \mathrm{Na}^{+}$, and other ions [44, 45]. Similarly, cations, anions, and conductivity in soil and water in the Kalapara coastal belt were recorded at an extremely toxic level. For instance, the soil conductivity was found to be $6.88 \mathrm{mS} / \mathrm{cm}$, while recommended values were $0.75-4$ for sustainable crop production. Moreover, several chemical properties of water samples such as conductivity (322.9 $\mathrm{S} / \mathrm{cm}), \mathrm{F}^{-}$(3.65), $\mathrm{Cl}^{-}$(5037.60), $\mathrm{SO}_{4}{ }^{2-}$ (557.34), $\mathrm{Na}^{+}$ (5184.94), and $\mathrm{K}^{+}$(78.89) were found at a more toxic level, whereas recommended values of conductivity, $\mathrm{F}^{-}, \mathrm{Cl}^{-}, \mathrm{SO}_{4}{ }^{2-}$, $\mathrm{Na}^{+}$, and $\mathrm{K}^{+}$were found to be $300(\mu \mathrm{S} / \mathrm{cm}), 1-2,150-600$, $250-400,200$, and $12 \mathrm{mg} / \mathrm{l}$, respectively (Table 7). According to Dusgupta et al. [1] thirty-nine (39) percent of salinity will be increased across the coastal belt in Bangladesh by 2050 . The intensity and spread of this salinity across the coastal belt in Bangladesh were connected with the changes of sea level rise, temperature, and rainfall and altered riverine flows from the Himalayas [46]. Agricultural production of crops, fish, and livestock has been negatively affected due to this extreme level of soil and water salinity trends across the coastal belt in Bangladesh.

Coastal agriculture is based on farmlands, which provide livelihood support for the community [47]. Several groups of people often suffer a shortage of freshwater in different areas of the coastal belt [48]. Many regions in the world along with the coastal belt of Bangladesh have used saline water for food crop cultivation, fodder crop production, drinking, and bathing [49]. These practices have contributed to the enormous negative effects on agricultural production systems as well as human health $[50,51]$. Coastal agriculture is predominantly affected by unequal water distribution over the last decades. This system causes an increase in salt levels in the crop fields as well as reduced yield [52]. Also, soil salinity has negatively affected rice yield, spikelet sterility, and 1000-grain weight in the coastal belt of Thailand as well as Bangladesh. In this regard, salinity is responsible for a $20 \%$ yield reduction of coastal region agriculture. In fact, the soil nutrient supply was only enough to achieve about $80 \%$ of the maximum yield [53]. In fact, this reduction of crop yield has been influenced by many environmental factors. Among these factors, salinity is one of the major causes for the yield reduction $[54,55]$. A similar result was found in these study locations where 92 percent of the cropping area is affected by the salinity problem. This remarkable salinity intrusion into the cropping areas has tremendously reduced the crop production across the coastal belt in Bangladesh (Table 9) which might have led to the shortage of food availability in Bangladesh.

Salinity has been convenient for shrimp cultivation across the coastal belt, but it has accelerated negative effects on the diversity of fresh water fish. Some of the inland fresh water species have become extinct due to the connectivity with saline water [56]. The rest of the fish species are only living in the fresh water ecosystem that are also likely to be extinct forever (Tables 10 and 11). Moreover, this salinity problem includes large-scale degradation of mangroves, alteration of wetlands, land subsidence, salinization of groundwater and surface water, pollution of agricultural lands and coastal waters by pond effluents and sludge, introduction of exotic species or pathogens into the coastal environment, loss of wild larvae, and subsequent loss of goods and services generated by natural common property resources [57]. However, 


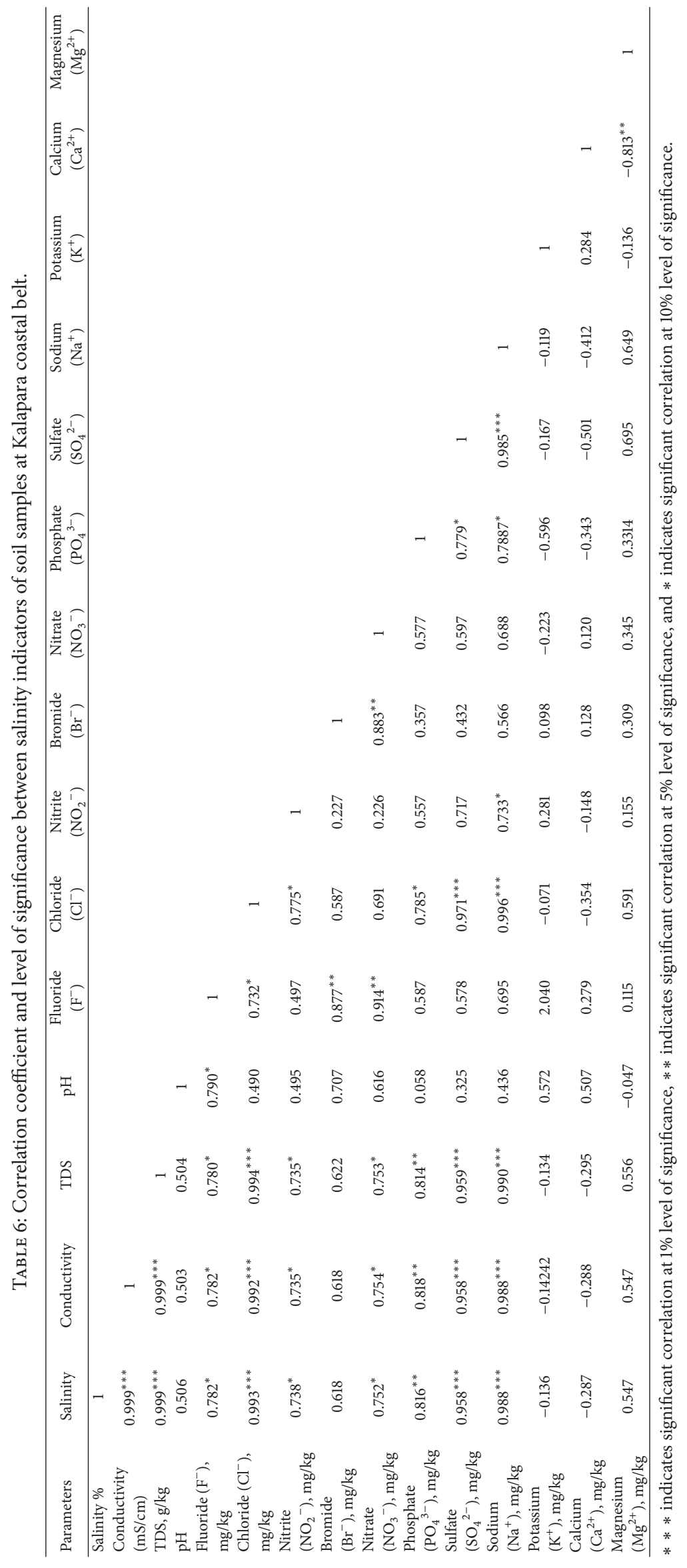


TABLE 7: Existing and recommended values of salinity indicators in soil and water samples.

\begin{tabular}{|c|c|c|c|c|c|}
\hline \multirow{2}{*}{ Samples } & \multirow{2}{*}{ Chemical properties } & \multirow{2}{*}{ Existing average values } & \multicolumn{3}{|c|}{ Recommended values } \\
\hline & & & DoE, 1997 [11] & USEPA, 1994 [12] & Horneck et al., 2007 [13] \\
\hline \multirow{15}{*}{ Water } & Salinity $\%$ & 1.88 & - & - & - \\
\hline & Electrical conductivity $(\mathrm{EC})(\mu \mathrm{S} / \mathrm{cm})$ & 322.9 & 300 & - & - \\
\hline & TDS, mg/l & 161.56 & 1000 & $500-1000$ & - \\
\hline & $\mathrm{pH}$ & 7.89 & $6.5-8.5$ & $6.5-8.5$ & - \\
\hline & Fluoride $\left(\mathrm{F}^{-}\right), \mathrm{mg} / \mathrm{l}$ & 3.65 & 1 & 2 & - \\
\hline & Chloride $\left(\mathrm{Cl}^{-}\right), \mathrm{mg} / \mathrm{l}$ & 5307.60 & $150-600$ & 250 & - \\
\hline & Nitrite $\left(\mathrm{NO}_{2}^{-}\right), \mathrm{mg} / \mathrm{l}$ & 0.85 & $<1$ & 1 & - \\
\hline & Bromide $\left(\mathrm{Br}^{-}\right), \mathrm{mg} / \mathrm{l}$ & 12.94 & - & - & - \\
\hline & Nitrate $\left(\mathrm{NO}_{3}{ }^{-}\right), \mathrm{mg} / \mathrm{l}$ & 4.17 & 10 & 10 & - \\
\hline & Phosphate $\left(\mathrm{PO}_{4}{ }^{3-}\right), \mathrm{mg} / \mathrm{l}$ & 1.05 & 6 & - & - \\
\hline & Sulfate $\left(\mathrm{SO}_{4}{ }^{2-}\right), \mathrm{mg} / \mathrm{l}$ & 557.34 & 400 & 250 & - \\
\hline & Sodium $\left(\mathrm{Na}^{+}\right), \mathrm{mg} / \mathrm{l}$ & 5186.94 & 200 & - & - \\
\hline & Potassium $\left(\mathrm{K}^{+}\right), \mathrm{mg} / \mathrm{l}$ & 78.89 & 12 & - & - \\
\hline & Calcium $\left(\mathrm{Ca}^{2+}\right), \mathrm{mg} / \mathrm{l}$ & 49.45 & 75 & - & - \\
\hline & Magnesium $\left(\mathrm{Mg}^{2+}\right), \mathrm{mg} / \mathrm{l}$ & 38.50 & $30-35$ & - & - \\
\hline \multirow{2}{*}{ Soil } & $\mathrm{pH}$ & 1.23 & - & - & $6.5-7.5$ \\
\hline & Electrical conductivity $(\mathrm{EC})(\mathrm{mS} / \mathrm{cm})$ & 6.688 & - & - & $0.75-4$ \\
\hline
\end{tabular}

Note. DoE stands for Department of Environment, USEPA (United States Environmental Protection Agency).

TABLE 8: Effects of salinity on crops, fisheries, and livestock at Kalapara coastal belt of Bangladesh.

\begin{tabular}{|c|c|c|}
\hline Crops & Fisheries & Livestock \\
\hline $\begin{array}{l}\text { Total cropping areas are } 39102 \text { hectare } \\
\text { (ha). During Aman season (June to } \\
\text { September), } 90 \% \text { of areas are covered by } \\
\text { rice. Salinity intrusion is highly visible } \\
\text { during dry season (October-May). } \\
\text { Cultivation of crops is at an extreme risk } \\
\text { as a result of high salinity intrusion. }\end{array}$ & $\begin{array}{l}\text { The number of fresh water bodies } \\
\text { recorded at Kalapara coastal area is } 18300 \\
\text { with total area of } 857 \text { ha. Out of these } \\
\text { areas, } 2-3 \% \text { are converted into shrimp } \\
\text { culture. Other areas are replaced by saline } \\
\text { water fish. Several occurrences of } \\
\text { adaptation are ongoing such as } \\
\text { introduction of crab fish and Koral and } \\
\text { salinity tolerance tilapia fish. }\end{array}$ & $\begin{array}{l}\text { About } 200 \text { ha grazing/fodder crop areas } \\
\text { have been affected each year due to } \\
\text { salinity intrusion. For this reason, food } \\
\text { shortage is one of the crucial issues for } \\
\text { livestock production in this coastal } \\
\text { region. Due to intake of salinity affected } \\
\text { fodder crops by livestock, several diseases } \\
\text { were found such as diarrhea, skin } \\
\text { diseases, liver fluke, loss of body weight, } \\
\text { and breakdown of immune system. }\end{array}$ \\
\hline
\end{tabular}

Data were collected from the office of Department of Agriculture and Extension (DAE), Department of Fisheries (DOF), and Department of Livestock Office (DLO) at Kalapar Upazila.

coastal areas are naturally vulnerable and survival strategies are very limited for people in these communities, so they prefer shrimp cultivation which is responsible for further increasing salinity (Sarwar, 2009). This saline water intrudes in the inland riverine areas which contributes to the reduction of fresh water bodies. This result is creating even more negative effects on the diversity of fish in the inland riverine areas across the coastal belt in Bangladesh (Tables 10 and 11).

An extreme scarcity of salinity free water was recorded in the coastal belt of Bangladesh because of natural disasters such as sea levels rising, cyclones, floods, and land erosion which brought saline water from the sea that mixed with surface and groundwater [58]. Water sources such as rivers, ponds, and tube wells are becoming unable to provide sustainable fresh water for people in the coastal community. Many key determinants of human health, such as food availability, fresh water availability, physical safety, and the microbiological environment, are strongly influenced by salinity [59]. As saline water mixes with inland water it becomes unsustainable for consumption by livestock and fish. People have started suffering from various kinds of health problem such as high blood pressure, diarrhea, and cholera [60]. Not only through water but also through consumption of food raised in these highly saline areas, people are getting more saline than they require for optimum health [61]. The most vulnerable groups are the pregnant women and the children. Higher rates of hypertension affecting pregnant women in the southwestern coast of Bangladesh, compared with noncoastal pregnant women, were hypothesized to be caused by salinity contamination [24]. Higher salinity from food grains also might have caused a higher rate of birth defects which is of great concern to the future of Bangladesh. Cholera sometimes spreads as an epidemic after a disaster such as flood or cyclone. Lack of drinking water and overconsumption of saline water influence malnutrition, 
TABLE 9: Effect of soil and water salinity on cropping patterns at Kalapara coastal belt.

\begin{tabular}{|c|c|c|c|}
\hline Description of cropping pattern & Total cultivable land (ha) & $\begin{array}{l}\text { Net cultivated land in } \\
\text { percentage (2014-15) }\end{array}$ & Causes \\
\hline Fallow-fallow-T. Aman & 21310 & 54.5 & Soil and water salinity \\
\hline Felon-fallow-T. Aman & 6251 & 15.99 & Soil and water salinity \\
\hline Pulse-fallow-T. Aman & 5160 & 13.2 & Soil and water salinity \\
\hline Watermelon-fallow-T. Aman & 2300 & 5.88 & Soil and water salinity \\
\hline Vegetables-fallow-T. Aman & 1200 & 3.07 & Drought \\
\hline Pulse-fallow-T. Aman & 381 & 0.97 & Soil and water salinity \\
\hline Felon-Aus-T. Aman & 356 & 0.91 & Soil and water salinity \\
\hline Boro-fallow-T. Aman & 275 & 0.70 & Soil and water salinity \\
\hline Vegetable-vegetable-vegetable & 257 & 0.66 & Drought \\
\hline Watermelon-Aus-T. Aman & 200 & 0.51 & Soil and water salinity \\
\hline Almond-fallow-T. Aman & 150 & 0.38 & Soil and water salinity \\
\hline Green chili-T. Aus-T. Aman & 120 & 0.31 & Soil and water salinity \\
\hline Pulse-Aus-T. Aman & 100 & 0.26 & Soil and water salinity \\
\hline Wheat-fallow-T. Aman & 100 & 0.26 & Salinity and drought \\
\hline Maize-fallow-T. Aman & 100 & 0.26 & Soil and water salinity \\
\hline Sweet potato-fallow-T. Aman & 100 & 0.26 & Soil and water salinity \\
\hline Pulse-fallow-T. Aman & 90 & 0.23 & Soil and water salinity \\
\hline Sunflower-fallow-T. Aman & 80 & 0.20 & Soil and water salinity \\
\hline Green chili-Aus-T. Aman & 80 & 0.20 & Soil and water salinity \\
\hline Almond-T. Aus-T. Aman & 50 & 0.13 & Soil and water salinity \\
\hline Sweet potato-T. Aus-T. Aman & 50 & 0.13 & Soil and water salinity \\
\hline Pulse-T. Aus-T. Aman & 50 & 0.13 & Soil and water salinity \\
\hline Sesame-fallow-T. Aman & 50 & 0.13 & Soil and water salinity \\
\hline Sunflower-Bona Aus-T. Aman & 40 & 0.10 & Soil and water salinity \\
\hline Wheat-T. Aus-T. Aman & 35 & 0.09 & Soil and water salinity \\
\hline Pulse-T. Aus-T. Aman & 31 & 0.08 & Salinity and drought \\
\hline Sweet potato-T. Aus-T. Aman & 30 & 0.08 & Soil and water salinity \\
\hline Fresh potato-T. Aus-T. Aman & 30 & 0.08 & Soil and water salinity \\
\hline Sugarcane-sugarcane-sugarcane & 21 & 0.05 & Drought \\
\hline Garlic-T. Aus-T. Aman & 20 & 0.05 & Soil and water salinity \\
\hline Wheat-T. Aus-T. Aman & 20 & 0.05 & Soil and water salinity \\
\hline Maize-T. Aus-T. Aman & 18 & 0.04 & Soil and water salinity \\
\hline Garlic-T. Aus-T. Aman & 16 & 0.04 & Soil and water salinity \\
\hline Vegetable-T. Aus-T. Aman & 15 & 0.04 & Salinity and drought \\
\hline Pulse-T. Aus-T. Aman & 15 & 0.04 & Salinity and drought \\
\hline Cucumber-T. Aus-T. Aman & 11 & 0.03 & Soil and water salinity \\
\hline $\begin{array}{l}\text { Total number of cropping } \\
\text { patterns is } 36\end{array}$ & $\begin{array}{l}\text { Total cropping area } \\
39,102 \text { ha }\end{array}$ & $\begin{array}{c}\text { Total cultivated areas in } \\
\text { percentages }(100 \%)\end{array}$ & $\begin{array}{c}92 \% \text { of areas are affected } \\
\text { by salinity }\end{array}$ \\
\hline
\end{tabular}

Note. T. Aman stands for Transplanted Aman Rice; T. Aus stands for Transplanted Aus Rice.

undernutrition, water borne diseases, and food borne diseases and even lead to starvation among coastal people [62].

Not only crops and fish have been negatively affected due to the high salt in the coastal belt of Bangladesh (Tables 8 , 9,10 , and 11). Saline water also has a detrimental effect on livestock production [63]. Survival of livestock is dependent on the field grass, water, and dairy feed. These types of natural resources are connected to saline water. Due to the shortage of fodder crops, livestock has been affected in this coastal region of Bangladesh (Table 8). Tolerance of the saline water varies between livestock species. Pregnant, lactating, and younger classes of livestock are less tolerant than mature dry stock. For optimum production in these classes of livestock, water supplies should not exceed the optimum salinity levels in the food for livestock [64]. Livestock grazing green feed can better tolerate salinity levels at the upper limit of each 
TABLE 10: Recorded species of fish at Kalapara coastal belt.

\begin{tabular}{|c|c|c|c|}
\hline Category & Local name & English name & Scientific name \\
\hline & Bhetki/Koral & Barramundi/Seabass & Lates calcarifer \\
\hline & Kalo bujuri & Tengra mystus & Mystus tengara \\
\hline & Tengra $^{* *}$ & Striped dwarf catfish & Mystus vittatus \\
\hline & Golsha tengra ${ }^{* * *}$ & Gangetic tengra & Mystus cavasius \\
\hline & Rui & Indian Major carp & Labeo rohita \\
\hline & Catla & Calta & Catla catla \\
\hline & Mrigal & Mrigal & Cirrhinus cirrhosus \\
\hline & Tara baim* & One-striped spiny eel & Macrognathus aculeatus \\
\hline & Baim/Guchi & Striped spiny eel & Macrognathus pancalus \\
\hline & Bele & Tank goby & Glossogobius giuris \\
\hline & Magur & Air breathing catfish & Clarias batrachus \\
\hline & Boal $^{*}$ & Freshwater shark & Wallago attu \\
\hline & Pabda & Pabdah catfish & Ompok pabda \\
\hline & Koi & Climbing perch & Anabas testudineus \\
\hline & Shol $^{* *}$ & Banded snakehead & Channa striata \\
\hline & Gazar & Giant snakehead & Channa marulius \\
\hline & Taki** $^{* *}$ & Spotted snakehead & Channa punctate \\
\hline & Cheng & Asiatic snakehead & Channa orientalis \\
\hline & Bheda/Meni* & Mud perch & Nandus nandus \\
\hline & Aor* & Long-whiskered catfish & Sperata aor \\
\hline & Foli $^{*}$ & Grey featherback & Notopterus notopterus \\
\hline & Chital & Humped featherback & Chitala chitala \\
\hline & Ilish $^{* *}$ & Hilsha & Tenualosa ilisha \\
\hline & Chandana ilish ${ }^{*}$ & Toli Hilsha & Tenualosa toil \\
\hline & Tit punti & Ticto barb & Puntius ticto \\
\hline & Jat punti** & Spotfin swamp barb & Puntius sophore \\
\hline & Sarpunti & Olive barb & Puntius sarana \\
\hline & Shing & Stinging cat fish & Heteropneustes fossilis \\
\hline & Chapila & Indian river shad & Gudusia chapra \\
\hline \multirow[t]{23}{*}{ Inland fishes } & Khalisha** & Striprd gourami & Colisa fasciatus \\
\hline & Mola & Indian carplet & Amblypharyngodon mola \\
\hline & Dhela* & Cotio & Osteobrama cotio \\
\hline & Kalibaus & Black rohu & Labeo calbasu \\
\hline & Darkina** & Rasbora & Rasbora rasbora \\
\hline & Kakila & Needle fish & Xenentodon cancila \\
\hline & Chanda & Elongate glass perch & Chanda nama \\
\hline & Pangus ${ }^{* * *}$ & River pungus & Pangasius pangasius \\
\hline & Ek thota ${ }^{* * *}$ & Halfback & Hyporhamphus limbatus \\
\hline & Potka ${ }^{* *}$ & Gangaetic puffer fish & Tetraodon patoca \\
\hline & Churi* $^{*}$ & - & Trichiurus muticus \\
\hline & Kuli $^{*}$ & Dusky sleeper & Elotris fusca \\
\hline & Tapasi/muni & Paradise threadfin & Polynemus paradiseus \\
\hline & Lakhua & Indian threadfin & Polydactylus indicus \\
\hline & Parsia* $^{*}$ & Goldspot mullet & Liza parsia \\
\hline & $\mathrm{Poa}^{* *}$ & Pama & Otolithoides pama \\
\hline & Somudra koi ${ }^{* * *}$ & Tripletail & Labotes surinamensis \\
\hline & Rup chanda & Chinese pomfret & Pampus chinensis \\
\hline & Tular dandi & Gangetic sillago & Silloginopsis panijus \\
\hline & Kuicha & Gangetic mud eel & Monopterus cuchia \\
\hline & Kani magur*** & Canine catfish eel & Plotosus canius \\
\hline & Rita* & Rita & Rita rita \\
\hline & Bata $^{*}$ & Bata labeo & Labeo bata \\
\hline
\end{tabular}


TABle 10: Continued.

\begin{tabular}{|c|c|c|c|}
\hline Category & Local name & English name & Scientific name \\
\hline & Phasa $^{*}$ & Gangetic hairfin anchovy & Setipinna phasa \\
\hline & Choukka** $^{* *}$ & Indian pellona & Pellona ditchela \\
\hline & Kachki** $^{* *}$ & Ganga river sprat & Corica soborna \\
\hline & Bagha air* & Gangetic goonch & Bagarius bagarius \\
\hline & Silong*** & Silond catfish & Silonia silondia \\
\hline & Salbaim ${ }^{* * *}$ & Zig Zag eel & Mastacembelus armatus \\
\hline & Chaka & Squarehead catfish & Chaca chaca \\
\hline \multirow{10}{*}{ Exotic fishes } & Grass carp & Asian carp & Ctenopharyngodon idella \\
\hline & Common carp & European carp & Cyprinus carpio \\
\hline & Silver carp & Asian carp & Hypophthalmichthys molitrix \\
\hline & Thai sarpunti/Raj puti & Firefine barb & Barbonymus gonionotus \\
\hline & Tilapia* & Cichlid fish & Oreochromis mossambica \\
\hline & Thai pungus* & - & Pangasianodon hypophthalmus \\
\hline & Nilotica* & - & Oreochromis niloticus \\
\hline & Bighead carp & - & Aristichthys nobilis \\
\hline & Mirror carp & - & Cyprinus carpio var. specularis \\
\hline & Black carp & - & Mylopharyngodon piceus \\
\hline \multirow{35}{*}{ Marine fishes } & Chitra/Bistara & Spotted butterfish & Scatophagus argus \\
\hline & Java & - & Siganus javus \\
\hline & Tular dandi ${ }^{*}$ & Lady fish & Sillago domina \\
\hline & $\operatorname{Med}^{* *}$ & Gaint sea cat fish & Katengus typus \\
\hline & Lal poa/Vola & Silver jew & Johnius argentatus \\
\hline & Konkon $^{* * *}$ & - & Pelamys chiliensis \\
\hline & Churi & Ribbon fish & Trichiurus haumela \\
\hline & Phasa $^{*}$ & Anchovies & Thryssa mystax \\
\hline & Datina/Sada datina** & Silver bream & Pomadasys hasta \\
\hline & Kani magur** & Canine eeltail catfish & Plotosus lineatus \\
\hline & Tular dandi & Gangetic sillago & Silloginopsis panijus \\
\hline & Kuicha & Gangetic mud eel & Monopterus cuchia \\
\hline & Kani magur & Canine catfish eel & Plotosus canius \\
\hline & Rup chanda & Chinese pomfret & Pampus chinensis \\
\hline & Cheowa $^{* * *}$ & Torpedo trevally & Taenoides anguillaris \\
\hline & Shaplapata/Haush & String ray & Himantura uarnak \\
\hline & Bhangan & Mullet & Mugil cephalus \\
\hline & Rekha** $^{* *}$ & Four barred finger fish & Corius quadrifasciatus \\
\hline & Loitta & Bombay duck & Harpadon nehereus \\
\hline & Foli chanda & Silver pomfret & Pampus argenteus \\
\hline & Rup chanda & Chinese pomfret & Pampus chinensis \\
\hline & Cheowa*** & Torpedo trevally & Taenoides anguillaris \\
\hline & Maitya* $^{*}$ & Jack and pompanos & Cybium guttatum \\
\hline & Lakhua & Indian salmon & Polynemus indicus \\
\hline & Sada poa & Silver jew & Otolithes argentatus \\
\hline & Gongonia $^{* *}$ & Grunting toadfish & Allenbatrachus grunniens \\
\hline & Amadi $^{* * *}$ & Pointed tail anchovy & Coilia dussumieri \\
\hline & Kukurjiv** $^{* *}$ & Sole & Cynoglossus macrostomus \\
\hline & Kamot hangor & Requiem shark & Carcharhinus gangetica \\
\hline & Bom maitta*** & Tuna & Euthynnus affinis \\
\hline & Bata $^{*}$ & - & Mugil cephalus \\
\hline & Ghagra bele* & - & Gobius personatus \\
\hline & Ghagra & Gagora catfish & Arius gagora \\
\hline & Somudra koi & Tripletail & Labotus surinamensis \\
\hline & Bhut bele** & - & Paragobiodon echinocephalus \\
\hline
\end{tabular}


TABLE 10: Continued.

\begin{tabular}{|c|c|c|c|}
\hline Category & Local name & English name & Scientific name \\
\hline & Somudra chela*** & - & Thryssa purava \\
\hline & Potka $^{* *}$ & - & Chelonodon patoca \\
\hline & Lambu/Bara poa* & Long jewfish & Sciaenoides brunneus \\
\hline & Foton maach & King mackerel & Scomberomorus guttatus \\
\hline & Ruppan* & Thread fun bream & Nemipterus japonicas \\
\hline & Moori & - & Caranyx speciosus \\
\hline & Choukha*** & Indian pellona & Pellona indica \\
\hline & Kawa* $^{*}$ & Hard tail & Megalapsis cordyla \\
\hline & Shankhachil & Banded eagle ray & Aetomylaeus nichofii \\
\hline & Katabukha ${ }^{* * *}$ & Beardless sea catfish & Batrachocephalus mino \\
\hline & $\mathrm{Kuli}^{* *}$ & Duckbill sleeper & Butis butis \\
\hline & Kamila & Indian pike conger & Congresox talabonoidis \\
\hline & Haturi hangor & Hammerhead shark & Eusphyra blochii \\
\hline & Tak chanda** & Common pony fish & Leiognathus equulus \\
\hline & Dahuk $^{*}$ & Walking goby & Scarteloas histophorus \\
\hline & Ilish $^{* *}$ & Hilsa shad & Tenualosa ilisha \\
\hline & Chandan ilish & Toli shad & Tenualosa toli \\
\hline & Tuna & Yellowfin tuna & Thunnus albacores \\
\hline & Ramchosh/Taposi $^{*}$ & Paradise threadfin & Polynemus paradiseus \\
\hline & Khorsula* $^{*}$ & Corsula & Rhinomugil corsula \\
\hline & Bhetki/Koral ${ }^{* * *}$ & Seabass & Lates calcarifer \\
\hline & Barguni* $^{*}$ & Jarbua terapon & Terapon jarbua \\
\hline & Rupsha** & Skipjack tuna & Katsuwonus pelamis \\
\hline \multirow{3}{*}{ Prawns } & Golda chingri $^{* *}$ & Fresh water prawn & Macrobrachium rosenbergii \\
\hline & Chatka chingri & - & Macrobrachium malcolmsonii \\
\hline & Gura chingri & Spider prawn & Macrobrachium tenuipes \\
\hline \multirow{5}{*}{ Shrimps } & Bagda chingri & Giant tiger shrimp & Penaeus monodon \\
\hline & Chaka chingri $^{* *}$ & Indian white shrimp & Penaeus indicus \\
\hline & Chapra chingri & Oriental shrimp & Penaeus orientalis \\
\hline & Horina chingri ${ }^{* * *}$ & Brown shrimp & Metapenaeus monoceros \\
\hline & Chali chingri & Yellow shrimp & Metapenaeus brevicornis \\
\hline \multirow{4}{*}{ Crabs } & Shela kakra & Mud crab & Scylla serrata \\
\hline & Zaji kakra** & Blue swimmer crab & Neptunus pelagicus \\
\hline & Sataru kakra & Swimmer crab & Neptunus sanguinolenta \\
\hline & Shela kakra & Mud crab & Scylla serrata \\
\hline
\end{tabular}

Note. Visible (without asterisk) indicates that species are available and are not considered in any remarkable risk; threatened $\left({ }^{*}\right)$ indicates that species are likely to become endangered within the foreseeable future; endangered $\left({ }^{* *}\right)$ indicates that species are becoming at risk of becoming extinct; extinct $\left({ }^{* * *}\right)$ indicates that there is no doubt that the last individual has died.

TABLE 11: Present status of recorded visible, threatened, endangered, and extinct fish species at Kalapara coastal belt.

\begin{tabular}{lccccc}
\hline Category & \% visible & \% threatened & \% endangered & \% extinct & Causes \\
\hline Inland fishes (59) & 45 & 24 & 19 & 12 & 12 \\
Marine fishes (57) & 43 & 21 & 24 & - & Cyclone/salinity \\
Exotic fishes (10) & 70 & 30 & - & 33 & - \\
Prawns (3) & 67 & - & 25 & - & Cyclone/salinity \\
Shrimps (4) & 50 & - & 25 & - & - \\
Crabs (4) & 75 & & & & - \\
\hline
\end{tabular}


category compared with those grazing dry feed or salt bush or on a high salt diet since the high water content of green feed will dilute the salinity levels of the water supply [65]. Salinity affected livestock may be able to transmit various diseases into human bodies. For this reason, salinity levels should be controlled in the coastal region for the production of livestock also.

\subsection{Mitigation Techniques}

3.6.1. Construction of Embankment across the Bank of Sea. Array of sea is connected with the inland riverine body. It should have been isolated through an embankment between the bank of the river and the sea. This land could be protected from inundation of saline water through the establishment of an embankment of suitable size. The recommended size should be 5-10 meters higher than the high tide level. Brammer [66] suggested that the Coastal Embankment Project is a requirement for protection from saline water crossing into the inland areas. He also recommended that it should have more consistent maintenance than in the past [66].

3.6.2. Provision of Sluice Gate on the Embankment. The sluice gate is a connection between inland and salt water bodies in the coastal region of Bangladesh. This sluice gate which is placed in the embankment systems is responsible for the control of excess water. This makes it possible to prevent intrusion of saline water during high tide in the coastal belt. This sluice gate across the embankment can remove excess saline water during high tide [2].

3.6.3. Leveling of Land. Slight variations in the land lead to salt accumulation in the crop fields. Land should be properly leveled to prevent accumulation of water in the low-lying patches with shallow groundwater tables and to facilitate a uniform drainage system for removing excess water. It will also help to apply irrigation water uniformly in the field during Rabi season (January-March), which will facilitate uniform germination of seeds and better growth of crops. Haque [2] recommends that the leveling of soil also supplies nutrients uniformly in the salinity affected crop fields.

3.6.4. Harvesting of Rain Water for Irrigation. Tidal water is generally salty. This water is not useful for the production of crops in the coastal belt. During the rainy season excess rain water should be stored in ponds and canals. Later, this harvested rain water will be valuable for crop irrigation during the dry season. Climate change has caused rising sea levels along the coastal belt. This in turn has contributed to the rise in salinity intrusion in the region. One result of this is a severe scarcity of potable water at the south western coastal area of Bangladesh. This rainwater harvesting system is proposed solution to provide fresh water for crop cultivation and domestic uses during the rainy season across the coastal belt in Bangladesh [67].

3.6.5. Salinity Tolerant Cultivars. Even though the coastal area is relatively flat, there exist some altitude differences in areas where depths of standing water can reach $10-100 \mathrm{~cm}$.
Varieties of cultivars should be selected on the basis of tolerance to standing water and the extent of salinity in the field to maximize productivity of the available land. Utilizing salt-tolerant crops is one of the most important strategies to solve the problem of salinity. Qualitative and quantitative protein synthesis in plants have been altered under these saline conditions. When a plant is subjected to abiotic stress, a number of genes are turned on, resulting in increased levels of several metabolites and proteins, some of which may be responsible for conferring a certain degree of protection from the salinity stress [68].

3.6.6. Introduction of Crop in Rabi (Winter) Season. Cropping intensity should be modified in slightly saline areas by adopting proper soil and water management practices with the introduction of salt-tolerant crop varieties. During this dry season, salt-tolerant minor cereal crops such as lentil, mung bean, and pea and different vegetables might be cultivated through the proper management of drainage systems [19].

3.6.7. Use of Fallowing Lands. Groundwater is saline and present at a shallow depth (about 1.0 meter). Keeping lands fallow leads to high salinity in soil due to the evaporation of excessive soil moisture. Therefore, it is recommended to avoid fallowing of lands during Rabi season (winter season). Salt-tolerant crops should be chosen and grown. This can be done by reintroduction of deep rooted perennial plants that continue to grow and use water during the seasons that do not support annual crop plants. This may restore the balance between rainfall and water use, thus preventing rising water tables and the movement of salt to the soil surface [69]. This will be helpful for maintaining of soil salinity profile.

3.6.8. Application of Potash Fertilizer. Since soils in general are poor in fertility with low organic matter content, it is necessary to apply appropriate fertilizers to increase crop production. Potash fertilizer has an added advantage in saline soil. It lowers $\mathrm{Na}$ uptake by plants and increases $\mathrm{K}$ uptake. Thus $\mathrm{K}$ fertilization protects crops from harmful effects of $\mathrm{Na}$. This crop nutrient management is one of the best options to increase the plant productivity in saline soils. For this, an application of potassium sulfate $\left(\mathrm{K}_{2} \mathrm{SO}_{4}\right)$ can improve the plant productivity and nutrient uptake for food crops in a saline environment. It was observed that the uptake and accumulation of nutrients like calcium, magnesium, potassium, and phosphorus increase in plants subjected to $\mathrm{K}$ fertilizer application under saline environments [70].

3.6.9. Reducing of Groundwater Level. In many parts of the coastal region, salinity is highly visible. To grow crops successfully in those areas, it is necessary to bring down the salinity by leeching the salts. It is also necessary to decrease the water table level and maintain it below the critical depth to prevent the salt from having an effect on crops. To achieve this objective, a proper subsurface drainage has to be installed to keep the groundwater at least 1.5 meters below the soil surface. Salinity is managed by a combination of vegetation and engineering strategies-designed to create the reduction of water in these areas. The planting of vegetation with high 
water usage can be utilized to reduce groundwater recharge and to intercept water as it moves through the soil [71].

3.7. Possible Adaptation Strategies and Practices. Strengthening adaptation capacity requires blending individual skills and household capacity with external institutional supports for technological acceptance. The dynamic geomorphological nature in coastal areas along with spontaneous natural disasters often exceeds the knowledge of the local people and use of available resources to reduce the problems in the long run. Adaptation practice is mostly dependent upon institutional response for promotional activities and to managing observed risks in Bangladesh and less focusing on integrating other social constructions at the community level. Making long-term decisions for coastal adaptation depends on climate change and complexities and levels of stakeholder support [72].

Coastal adaptation can be reached through adjustment of ecological, social, or economic systems to actual or expected climatic impacts. Social, ecological, and institutional capacities are significantly important to the coastal communities to adapt themselves in an adverse situation. These communities of people need to adapt with the changing environmental conditions caused by salinity. They have been following traditional cropping patterns for crop cultivation across the coastal saline environment [73]. They have continued to adapt during the period of rapid change since the 1950s when the first major flood embankments were constructed and, later, with the spread of dry-season irrigation and the introduction of high-yielding crop varieties. In this situation, it is highly recommended to change the traditional cropping patterns as per the guidelines of Agriculture Extension Department in Bangladesh to ones that will provide more protection from salinity intrusion across this costal belt.

Introducing fast growing and improved varieties fish across the costal belt might be a way of supplying fresh water fish. Though coastal areas are dominated by groups of fishermen, with the changing environment and extreme events, most of the people are experiencing a decrease in the seasonal fish catch from the sea and rivers in the region. The channel system can secure additional or alternative sources of income through fish cultivation in two seasons of the year. By excavating a single ditch, a family can produce an estimated $200 \mathrm{~kg}$ of fish annually which secures their household protein and additional income after consumption. Harvesting of rain water in these ditches also supports regular water supply to plantations on the channel and increases fresh water security as it doubles as a reservoir.

The plantation of the correct varieties of vegetables can provide an immediate opportunity for household consumption in these communities. Different hanging vegetables including country bean, cucumber, bottle, bitter, and sweet gourds (cucurbitaceous vegetables) and other creeper vegetables may be cultivated widely across the coastal belt. This cultivation system will be helpful for supplying needed nutrients during adverse conditions of salinity intrusion across the coastal environment.

Agricultural practice is increasingly constrained with a high level of salinity ingress and frequent and severe impacts of natural disasters in coastal areas. Given the impacts of seasonal water logging and salinity on land and lack of irrigation in dry seasons, alternative cropping practices through use of climate resilient rice varieties have been a vital need for agricultural production in the area. The salttolerant rice variety (BR 47) has already been introduced in four coastal districts. Considering lower land productivity, this rice variety has been considered a potential crop in this coastal area. This BR 47 rice variety might be introduced due to its high yield in extreme saline conditions in this coastal region.

\subsection{Policy Implications and Gaps in These Salinity Affected Areas}

3.8.1. Fragile Water Governance Systems at Local Level. Weak water governance systems at the local level are another cause of the salinity increase. Salinity intrusion not only is a natural phenomenon but also is caused by human activities. Numerous human activities-such as untimely water use, unplanned shrimp culture, insufficient or poorly maintained infrastructure, and inadequate management systems-can contribute to salinity intrusion.

3.8.2. Cross Boundary River Policy. A total of 57 major rivers are located in the country of Bangladesh, of which 54 rivers enter from India and 3 rivers from Myanmar [74]. But among the 54 rivers, twenty-five rivers face one or more upstream diversions primarily in the dry months. For this reason, water scarcity during nonmonsoon months causes the salinity to increase in the soil and water of the coastal belt of Bangladesh.

3.8.3. Lack of Capacity of Local Government. Local government reforms in Bangladesh have evolved very distinctly according to the needs of the ruling elites [75]. With the change of government, the policy of local government has also kept changing. As a consequence, Local Government Institute (LGI) has not had any opportunity to act with any effective tiers of government because mandates and limited funds prevent them from being able to carry out their roles and responsibilities. Independent reviews stated that Bangladesh has not been successful in establishing a decentralized system of governance and accountability. A World Bank review of the decentralization process in 19 countries ranks Bangladesh lowest in the decentralization scale [76]. Due to the lack of capacity of LGIs, they cannot take the initiative to protect coastal polders, embankments, roads, and other kinds of infrastructure as well as the unplanned shrimp culture. As a result, salinity has continued to increase across the costal belt in Bangladesh.

3.8.4. Weak Structure and Poor Maintenance. Bangladesh has a $5,017 \mathrm{~km}$ embankment protecting the polders in coastal areas of the Bay of Bengal. The primary goal of launching polderization in Bangladesh was to protect the coastal inhabitants from regular natural disasters and to boost the agricultural production [77]. Bangladesh Water Development 
Board (BWDB) formerly known as Water and Power Development Authority (WAPDA) is in charge of maintaining and conducting the rehabilitation project of the polders [78]. But due to the poor maintenance, coastal polders in many places have not been protected from salinity intrusion into the agricultural fields. The BWDB has categorized 51 polders as "most vulnerable" and another 55 polders as "medium vulnerable." To cope with vulnerability, it is necessary to rehabilitate the damaged infrastructure of the polders. Most of the sluice gates have been damaged which enables the saline water to continuously flow inland. In addition, shrimp farmers cut the embankment to get saline water into their shrimp fields which also makes the embankment weak. This weak embankment is easily damaged due to tidal pressure, particularly during full moon, and the saline water can then enter the polders.

3.8.5. Lack of Coordination among Different Organization. Local government has connected with the federal government. Government personnel in the departments of extension, disasters, fisheries, livestock, engineering, and water development boards might have a lack of coordination to be able to implement any of the government policies together. On the contrary, researchers, nongovernment officers (NGOs), and international and national groups have been working without coordination with the national government. Due to the lack of integration between the organizations, proposed activities for the reduction of salinity across the coastal belt have not been substantially implemented throughout the country.

\section{Conclusion}

The coastal belt is at an extreme risk due to high soil and water salinity. This salinization in water and soil is the major natural hazard hampering crop and livestock production. This is also producing a negative impact on the diversity of fish across this costal belt. This coastal area in Bangladesh constitutes $20 \%$ of the country of which about $53 \%$ is affected by different degrees of salinity. In fact, declining land, fish, and livestock productivity with a shift toward negative nutrient balance is among the main concerns for food security problems in the country. Several cations and anions in water and soil such as conductivity, $\mathrm{F}^{-}, \mathrm{Cl}^{-}, \mathrm{SO}_{4}{ }^{2-}$, $\mathrm{Na}^{+}$, and $\mathrm{K}^{+}$were found at higher than recommended values for a sustainable environment across the Kalapara coastal belt of Bangladesh. About 200 ha fodder crop areas are affected each year due to salinity. Among 36 cropping patterns, 92 percent of these were identified as salinity affected areas. Out of 857 ha water bodies, $2-3 \%$ are occupied by shrimp culture which has contributed to the salinity of inland and fresh water bodies across the coastal belt. Twenty-five percent of shrimp species were recorded in the extinct category. Due to the weak policy implementation, this salinity problem is increasing which has enhanced the negative impacts on food security. It is significantly important to explore the possibilities for increasing agricultural production for the growing population throughout the world as well as the coastal region of Bangladesh. Thus, combating this land salinization problem is a vital issue for food security in the country through adoption of long-term land management strategies.

\section{Disclosure}

This research is a national issue for Bangladesh. The authors are all working in the Government Institute of Bangladesh. Their job is to conduct research and teaching on the national issues in Bangladesh. For this reason, they do not need to receive approval for sample collection from any authority of Bangladesh. Sampling areas are not indicated as protected or endangered species areas in Bangladesh.

\section{Conflicts of Interest}

The authors declare that no conflicts of interest exist regarding the publication of this paper.

\section{Acknowledgments}

The authors would like to acknowledge the Laboratory of Environmental Science at Bangabandhu Sheikh Mujibur Rahman Agricultural University (BSMRAU) and Biological Research Division at Soil and Environment Section of Bangladesh Council of Scientific and Industrial Research (BCSIR). The authors are also thankful to the Department of Agricultural Extension (DAE), Department of Fisheries (DOF), and Department of Livestock Services (DLS) at Kalapara Upazila for their support to collect data on salinity issues across the coastal belt of Bangladesh. Finally, they are especially thankful to the Ministry of Science and Technology, Bangladesh, for their valuable funding.

\section{References}

[1] S. Dasgupta, M. M. Hossain, M. Huq, and D. Wheeler, "Climate change and soil salinity: The case of coastal Bangladesh," Ambio, vol. 44, no. 8, pp. 815-826, 2015.

[2] S. A. Haque, "Salinity problems and crop production in coastal regions of Bangladesh," Pakistan Journal of Botany, vol. 38, no. 5, pp. 1359-1365, 2006.

[3] W. Palash, Salinity in the South West Region of Bangladesh and the Impact of Climate Change, 2015, http://www.studentswaterdiplomacy.org/blog/2015/4/8/salinity-in-the-south-westregion-of-bangladesh-and-impact-of-climate-change.

[4] S. Huq and G. Rabbani, 2011, Adaptation Technologies in Agriculture; The Economics of rice farming technology in climate vulnerable areas of Bangladesh.

[5] Soil Resources Development Institute (SRDI), Saline Soils of Bangladesh; SRDI, Ministry of Agriculture, Dhaka, Bangladesh, 2010.

[6] M. S. Iftekhar and M. R. Islam, "Managing mangroves in Bangladesh: a strategy analysis," Journal of Coastal Conservation, vol. 10, no. 1-2, pp. 139-146, 2004.

[7] M. Mahmuduzzaman, Z. U. Ahmed, A. K. M. Nuruzzaman, and F. R. S. Ahmed, "Causes of Salinity Intrusion in Coastal Belt of Bangladesh," nternational Journal of Plant Research, vol. 4, no. 4A, pp. 8-13, 2014. 
[8] Ocean Health, Chemistry of sea water, 2017, http://oceanplasma .org/documents/chemistry.html.

[9] A. Basar, "Water Security in Coastal Region of Bangladesh," Bangladesh e-Journal of Sociology, vol. 9, p. 2, 2012.

[10] S. Huq, Vulnerability and Adaptation to Climate Change for Bangladesh, Kluwer Academic Publishers, 1999.

[11] DoE (Department of Environment), The environment conservation rules 1997, Ministry of Environment and Forest, Dhaka, Bangladesh, 1997.

[12] USEPA (United States Environmental Protection Agency), Water-quality criteria, standards, or recommended limits for selected properties and constituents. Hydrology of the black hills area, South Dakota.pp 46-49, 1994, https://pubs.usgs.gov/ wri/wri024094/pdf/mainbodyofreport-3.pdf.

[13] D. A. Horneck, J. W. Ellsworth, B. G. Hopkins, D. M. Sullivan, and R. G. Stevens, Managing Salt-affected Soils for Crop Production. A Pacific Northwest Extension publication Oregon State University, University of Idaho and Washington State University, https://eal.byu.edu/Portals/100/docs/Additional\% 20Resources/Managing\%20Salt-Affected\%20Soils\%20for\% 20Crop\%20Production.pdf.

[14] Climate Change Cell, 2009, Climate Change Adaptation Research: Adaptive Crop Agriculture Including Innovative Farming Practices in the Coastal Zone of Bangladesh, DOE, MOEF, Component 4b, CDMP, MOFDM.

[15] J. E. Bauer, W.-J. Cai, P. A. Raymond, T. S. Bianchi, C. S. Hopkinson, and P. A. G. Regnier, "The changing carbon cycle of the coastal ocean," Nature, vol. 504, no. 7478, pp. 61-70, 2013.

[16] M. K. Papademetriou and F. J. Dent, Crop Diversification in the Asia-Pacific Region, Food and Agriculture Organization, Bangkok, Thailand, 2001.

[17] R. G. Allen, L. S. Pereira, D. Raes, and M. Smith, Cropevapotranspiration-guidelines for computing crop water requirementsFAO Irrigation and drainage paper 56, Food and Agriculture Organization, Food and Agriculture Organization, Rome, Italy, 1998.

[18] M. Rashid and M. S. Islam, Bangladesh country paper for the $3 \mathrm{rd}$ session of the Technical Committee of Asian and Pacific Center for Agricultural Engineering and Machinery (APCAEM), Beijing, China, 2007.

[19] D. Clarke, S. Williams, M. Jahiruddin, K. Parks, and M. Salehin, "Projections of on-farm salinity in coastal Bangladesh," Environmental Sciences: Processes and Impacts, vol. 17, no. 6, pp. 1127-1136, 2015.

[20] M. A. Allison, S. R. Khan, J. Goodbred, and S. A. Kuehl, "Stratigraphic evolution of the late Holocene Ganges-Brahmaputra lower delta plain," Sedimentary Geology, vol. 155, no. 3-4, pp. 317-342, 2003.

[21] M. Rahman and A. Bhattacharya, "Salinity intrusion and its management aspects in Bangladesh," J Environ Hydrol, vol. 14, pp. 1-8, 2006.

[22] A. A. Rahman and P. Ravenscroft, Groundwater Resources and Development in Bangladesh, Centre for Advanced Studies, University Press Ltd., 2nd edition, 2003.

[23] Integrated Regional Information Networks, 2007, Bangladesh: Rising Sea Levels Threaten Agriculture. http://www.irinnews .org/report.aspx?ReportId=75094.

[24] A. E. Khan, A. Ireson, S. Kovats et al., "Drinking water salinity and maternal health in coastal Bangladesh: implications of climate change," Environmental Health Perspectives, vol. 119, no. 9, pp. 1328-1332, 2011.
[25] MOEF (Ministry of Environment and Forest), Impact of SeaLevel Rise on Land Use Suitability and Adaptation Options: Coastal Land Zoning in the Southwest, Ministry of Environment and Forest, Dhaka, Bangladesh, 2006.

[26] A. Wistrand, "Shrimp farming in Bangladesh," in The Blues of a Revolution: The Damaging Impacts of Shrimp Farming, D. Torre and D. Barnhizer, Eds., 2003.

[27] A. Kendrick, The Gher Revolution: The Social Impacts of Technological change in Freshwater Prawn Cultivation in Southern Bangladesh. Bangladesh Aquaculture and Fisheries Resource Unit, Dhaka, 1994, https://www.cambridge.org/core/ journals/renewable-agriculture-and-food-systems/article/divclasstitlesalinity-effects-on-food-habits-in-three-coastal-ruralvillages-in-bangladeshd.

[28] M. H. Rahman, T. Lund, and I. Bryceson, "Salinity effects on food habits in three coastal, rural villages in Bangladesh," Renewable Agriculture and Food Systems, vol. 26, no. 3, pp. 230242, 2011.

[29] S. Brucet, D. Boix, L. W. Nathansen et al., "Effects of temperature, salinity and fish in structuring the macroinvertebrate community in shallow lakes: Implications for effects of climate change," PLoS ONE, vol. 7, no. 2, Article ID e30877, 2012.

[30] WHO (World Health Organization), Guidelines for DrinkingWater Quality, Geneva, Switzerland, 3rd edition, 2008.

[31] A. Khan, S. K. Mojumder, S. Kovats, and P. Vineis, "Saline contamination of drinking water in Bangladesh," The Lancet, vol. 371, no. 9610, p. 385, 2008.

[32] WHO (World Health Organization), Public Health InitiativesHealth Impact of Highly Saline Water, Geneva, Switzerland, 2003.

[33] Statistical Pocketbook Bangladesh, Upazila/Thana-wise Area, Household and Population of Bangladesh, 2001 and 2011. Statistics and Informatics Division (SID), Ministry of Planning, Government of the People's Republic of Bangladesh. 71, 2016, http://203.112.218.65/WebTestApplication/userfiles/Image/LatestReports/PB2015.pdf.

[34] A. K. De, Environmental Chemistry, Wiley Eastern Ltd, New Delhi, India, 1989.

[35] M. L. Jackson, Soil Chemical Analysis, Prentice Hall, Inc., Englewood Cliffs, NJ, USA, 1967.

[36] D. K. Todd, Ground Water Hydrology, Jhon Willy and Sons. Inc, New York, NY, USA, 1980.

[37] APHA, Standard Methods for the Examination of Water and Wastewater, American Public Health Association, Washington, DC, USA, 20th edition, 1998.

[38] SSSA (Soil Science Society of America), Methods of Soil Analysis, Part 3, Chemical Methods. Soil Science Society of America, American Society of Agronomy, Madison, Wis, USA, 1996.

[39] J. Hunt, "Determination of total sulphur in small amounts of plant material," The Analyst, vol. 105, no. 1246, pp. 83-85, 1980.

[40] APHA, Standard Methods for the Examination of Water and Wastewater, American Public Health Association, Washington, DC, USA, 2st edition, 2005.

[41] National Association of Testing Authorities (NATA), The use of certified reference materials in testing /calibration and the role of proficiency testing, 2008, https://www.nata.com.au/nata/.

[42] National Environment Protection Measure (NEPM), Laboratory analysis of potentially contaminated Soils, 2011, http:// www.nepc.gov.au/system/files/resources/93ae0e77-e697-e494656f-afaaf9fb4277/files/schedule-b3-guideline-laboratory-analysis-potentially-contaminated-soils-sep10.pdf. 
[43] H. Asbjornsen, A. S. Mayer, K. W. Jones et al., "Assessing impacts of payments for watershed services on sustainability in coupled human and natural systems," BioScience, vol. 65, no. 6, pp. 579591, 2015.

[44] P. A. Gale, N. Busschaert, C. J. E. Haynes, L. E. Karagiannidis, and I. L. Kirby, "Anion receptor chemistry: Highlights from 2011 and 2012," Chemical Society Reviews, vol. 43, no. 1, pp. 205-241, 2014.

[45] S. A. El-Swaify, "Soil and Water Salinity Plant Nutrient Management in Hawaiis Soils, Approaches for Tropical and Subtropical Agriculture," in College of Tropical Agriculture and, J. A. Silva and and R. Uchida, Eds., College of Tropical Agriculture and Human Resources, University of Hawaii, 2000.

[46] S. Dasgupta, F. A. Kamal, Z. H. Khan, S. Choudhury, and N. Nishat, River salinity and climate change: Evidence from coastal Bangladesh. Policy Research Working Paper No. 6817, Development Research Group, World Bank, Washington, DC, USA, 2014.

[47] A. J. Hamilton, K. Burry, H.-F. Mok, S. F. Barker, J. R. Grove, and V. G. Williamson, "Give peas a chance? Urban agriculture in developing countries. A review," Agronomy for Sustainable Development, vol. 34, no. 1, pp. 45-73, 2014.

[48] FAO (Food and Agricultural Organization), in Integrated Coastal Area Management and Agriculture, Forestry, Fisheries, and Scialabban, Eds., FAO Guidelines. Environment and Natural Resources Service, Rome, Italy, 1998.

[49] J. D. Woodruff, J. L. Irish, and S. J. Camargo, "Coastal flooding by tropical cyclones and sea-level rise," Nature, vol. 504, no. 7478, pp. 44-52, 2013.

[50] C. B. Ahmed, S. Magdich, B. B. Rouina, M. Boukhris, and F. B. Abdullah, "Saline water irrigation effects on soil salinity distribution and some physiological responses of field grown Chemlali olive," Journal of Environmental Management, vol. 113, pp. 538-544, 2012.

[51] M. Z. Alam, L. Carpenter-Boggs, A. Rahman et al., "Water quality and resident perceptions of declining ecosystem services at Shitalakka wetland in Narayanganj city," Sustainability of Water Quality and Ecology, 2016.

[52] M. Das, R. R. Sethi, and N. Sahoo, "Evaluation and integration of soil salinity and water data for improved land use of underproductive coastal area in Orissa," Irrigation and Drainage, vol. 59, no. 5, pp. 621-627, 2010.

[53] C. Clermont-Dauphin, N. Suwannang, O. Grünberger, C. Hammecker, and J. L. Maeght, "Yield of rice under water and soil salinity risks in farmers' fields in northeast Thailand," Field Crops Research, vol. 118, no. 3, pp. 289-296, 2010.

[54] H. Eren, M. Y. Pekmezci, S. Okay et al., "Hexaploid wheat (Triticum aestivum) root miRNome analysis in response to salt stress," Annals of Applied Biology, vol. 167, no. 2, pp. 208-216, 2015.

[55] E. V. Mass and G. J. Hoffman, "Crop salt tolerance- current assessment,” ASCE J. Irrig. Drai. Div, vol. 103, no. 2, pp. 115-134, 1977.

[56] M. Orr, "Fish with a different angle: The fresh-water fishes of great britain by mrs Sarah Bowdich (1791-1856)," Annals of Science, vol. 71, no. 2, pp. 206-240, 2014.

[57] A. K. Azad, K. R. Jensen, and C. K. Lin, "Coastal aquaculture development in Bangladesh: Unsustainable and sustainable experiences," Environmental Management, vol. 44, no. 4, pp. 800-809, 2009.
[58] R. A. Wurbs and C. Lee, "Incorporation of salinity in Water Availability Modeling," Journal of Hydrology, vol. 409, no. 1-2, pp. 451-459, 2011.

[59] D. Tilman and M. Clark, "Global diets link environmental sustainability and human health," Nature, vol. 515, no. 7528, pp. 518-522, 2014.

[60] A. Azizullah, M. N. K. Khattak, P. Richter, and D. Häder, "Water pollution in Pakistan and its impact on public health-a review," Environment International, vol. 37, no. 2, pp. 479-497, 2011.

[61] U. Patnaik, "Export-oriented agriculture and food security in developing countries and India," Economic and Political Weekly, vol. 31, no. 35/37, pp. 2429-2449, 1996.

[62] S. Cervero-Aragó, S. Rodríguez-Martínez, A. Puertas-Bennasar, and R. M. Araujo, "Effect of common drinking water disinfectants, chlorine and heat, on free Legionella and amoebaeassociated Legionella," PLoS ONE, vol. 10, no. 8, Article ID e0134726, 2015.

[63] H. C. Duong, A. R. Chivas, B. Nelemans et al., "Treatment of $\mathrm{RO}$ brine from CSG produced water by spiral-wound air gap membrane distillation-a pilot study," Desalination, vol. 366, pp. 121-129, 2015.

[64] G. Stoeglehner, P. Edwards, P. Daniels, and M. Narodoslawsky, "The water supply footprint (WSF): A strategic planning tool for sustainable regional and local water supplies," Journal of Cleaner Production, vol. 19, no. 15, pp. 1677-1686, 2011.

[65] Government of Western Australia (Department of Agriculture and Food), 2016, Water quality for livestock, https://www .agric.wa.gov.au/livestock-biosecurity/water-quality-livestock.

[66] H. Brammer, "Bangladesh's dynamic coastal regions and sealevel rise," Climate Risk Management, vol. 1, pp. 51-62, 2014.

[67] K. Z. Islam, M. S. Islam, J. O. Lacoursière, and L. Dessborn, "Low Cost Rainwater Harvesting: An Alternate Solution to Salinity Affected Coastal Region of Bangladesh," American Journal of Water Resources, vol. 2, no. 6, pp. 141-148, 2014.

[68] P. Bhatnagar-Mathur, V. Vadez, and K. K. Sharma, "Transgenic approaches for abiotic stress tolerance in plants: retrospect and prospects," Plant Cell Reports, vol. 27, no. 3, pp. 411-424, 2008.

[69] G. Manchanda and N. Garg, "Salinity and its effects on the functional biology of legumes," Acta Physiologiae Plantarum, vol. 30, no. 5, pp. 595-618, 2008.

[70] A. Kausar, M. Y. Ashraf, M. Gull et al., "Alleviation of salt stress by $\mathrm{K} 2 \mathrm{SO} 4$ in two wheat (Triticum Aestivum L.) cultivars," Applied Ecology and Environmental Research, vol. 14, no. 5, pp. 137-147, 2016.

[71] Department of Environment and Resource Management, 2017, Managing salinity with vegetation. Queensland government, https://www.qld.gov.au/dsiti/assets/soil/managing-salinitywith-vegetation.pdf.

[72] E. L. Tompkins, R. Few, and K. Brown, "Scenario-based stakeholder engagement: Incorporating stakeholders preferences into coastal planning for climate change," Journal of Environmental Management, vol. 88, no. 4, pp. 1580-1592, 2008.

[73] H. Brammer, Can Bangladesh be protected from Floods? University Press Ltd, Dhaka, Bangladesh, 2004.

[74] A. Rounak and M. A. Rahman, "Transboundary River Water for Ganges and Teesta Rivers in Bangladesh: An Assessment," Global Science and Technology Journal, 2013.

[75] K. Westergaard, "Decentralization in Bangladesh: Local government and NGOs," in Paper prepared for presentation at the Colloquium on Decentralization and Development at Department of Political Science, Center for Development Research, Copenhagen, Denmark, 2000. 
[76] M. Williams, M. Keith, and K. Graham, Decentralization and Rural Development: Characterizing Efforts in 19 Selected Countries, World Bank, 1998.

[77] R. Shaw, "Critical issues of community based flood mitigation: examples from Bangladesh and Vietnam," Science and Culture, vol. 72 , no. $1 / 2,2006$.

[78] J. W. Thomas, "Development Institutions, Projects, and Aid: A Case Study of the Water," 1974. 

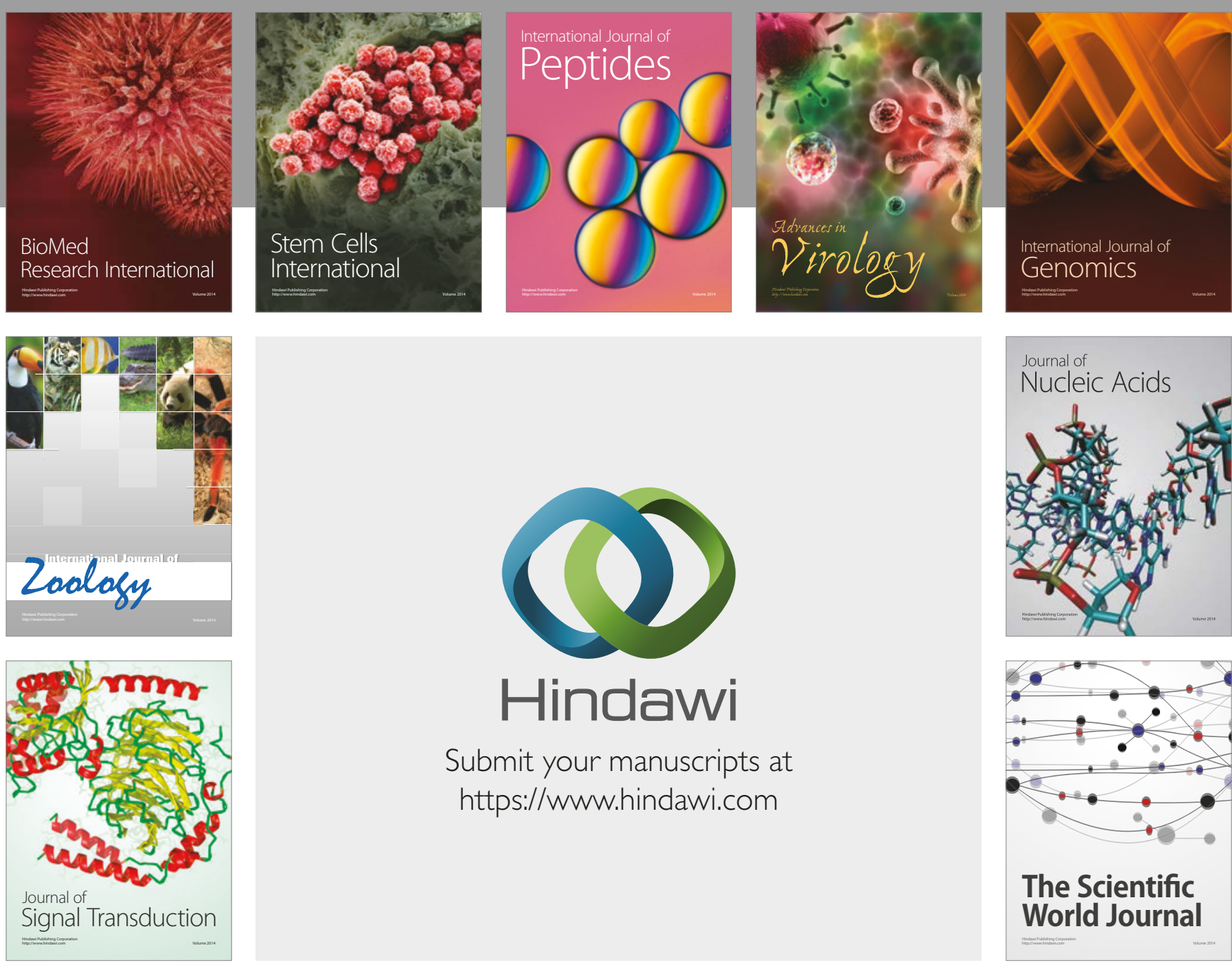

Submit your manuscripts at

https://www.hindawi.com
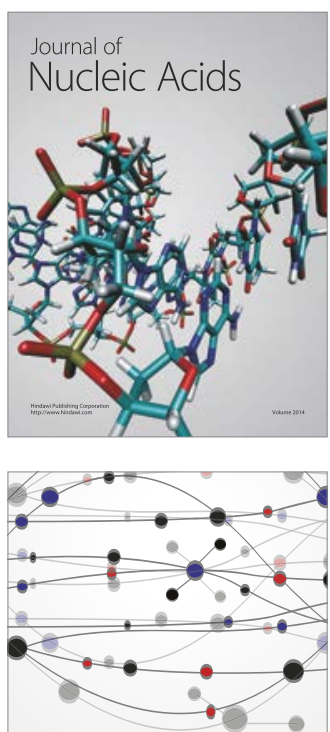

The Scientific World Journal

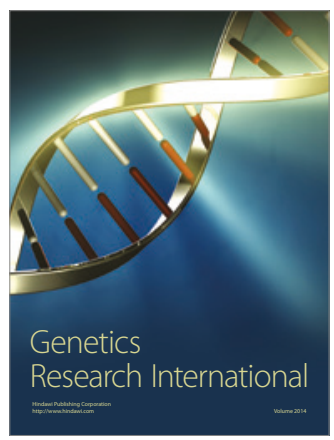

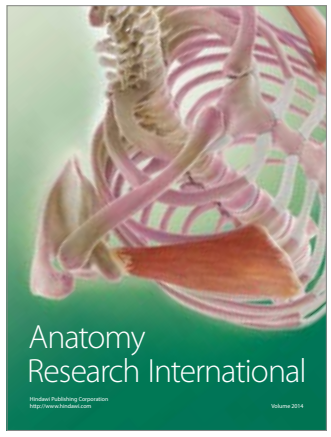

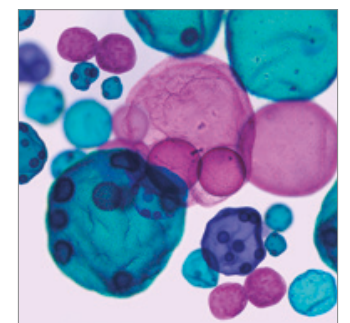

International Journal of Microbiology
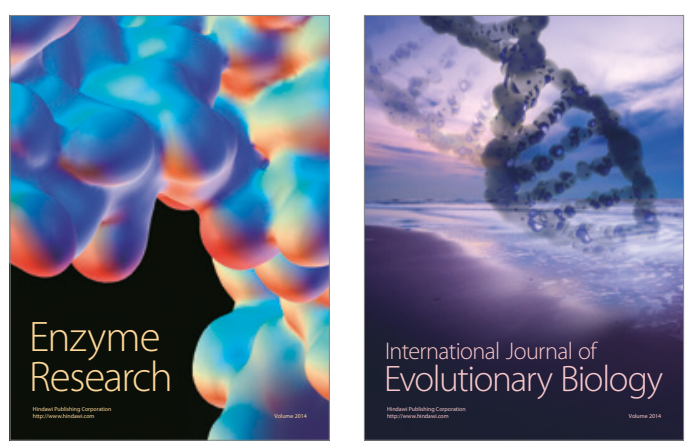
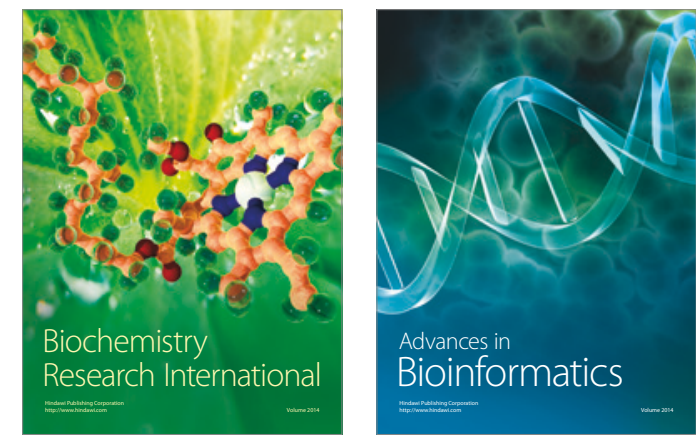

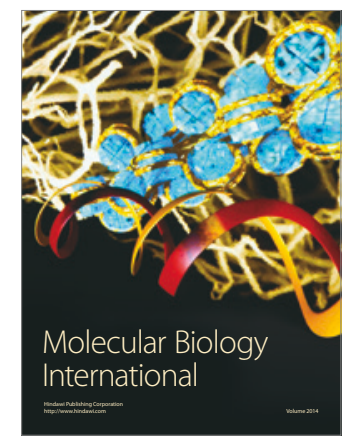

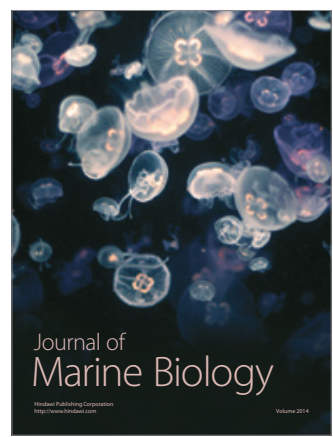

